\title{
Tectono-Sedimentary Cenozoic Evolution of the El Habt and Ouezzane Tectonic Units (External Rif, Morocco)
}

\author{
Manuel Martín-Martín 1,*DiD, Francesco Guerrera ${ }^{2} \mathbb{D}$, Rachid Hlila ${ }^{3}$, Alí Maaté ${ }^{3}$, Soufian Maaté ${ }^{4}$, \\ Mario Tramontana ${ }^{5}$ (D), Francisco Serrano ${ }^{6}$, Juan Carlos Cañaveras ${ }^{1}$, Francisco Javier Alcalá ${ }^{7,8}$ (D) \\ and Douglas Paton 9 \\ 1 Departamento de Ciencias de la Tierra y Medio Ambiente, University of Alicante, 03080 Alicante, Spain; \\ jc.canaveras@ua.es \\ 2 Ex-Dipartimento di Scienze della Terra, della Vita e dell'Ambiente (DiSTeVA), Università degli Studi di \\ Urbino Carlo Bo, 61029 Urbino, Italy; francesco@guerrera.biz \\ 3 Laboratoire de Géologie de l'Environnement et Ressources Naturelles, Département de Géologie, \\ Université Abdelmalek Essaâdi, Tétouan 93002, Morocco; rhlila@yahoo.com (R.H.); \\ amaate@uae.ac.ma (A.M.) \\ 4 Faculté des Sciences et Techniques Errachidia, Université Moulay Ismail Département de Géosciences, \\ Errachidia 52000, Morocco; soufian.maate@gmail.com \\ 5 Dipartimento di Scienze Pure e Applicate (DiSPeA), Università degli Studi di Urbino Carlo Bo, \\ 61029 Urbino, Italy; mario.tramontana@uniurb.it \\ 6 Departamento de Geología y Ecología, University of Málaga, 29016 Málaga, Spain; F.Serrano@uma.es \\ 7 Instituto Geológico y Minero de España, 28003 Madrid, Spain; francisco.alcala.fa01@gmail.com \\ 8 Instituto de Ciencias Químicas Aplicadas, Facultad de Ingeniería, Universidad Autónoma de Chile, \\ 7500138 Santiago, Chile \\ 9 School of Earth and Environment, University of Leeds, Leeds LS2 9JT, UK; D.A.Paton@leeds.ac.uk \\ * Correspondence: manuel.martin.m3@gmail.com
}

Received: 12 November 2020; Accepted: 1 December 2020; Published: 3 December 2020

\begin{abstract}
An interdisciplinary study based on lithostratigraphic, biostratigraphic, petrographic and mineralogical analyses has been performed in order to establish the Cenozoic tectono-sedimentary evolution of the El Habt and Ouezzane Tectonic Units (External Intrarif Subzone, External Rif, Morocco). The reconstructed record allowed identification of the depositional architecture and related sedimentary processes of the considered units. The Cenozoic successions were biochronologically defined allowing, at the same time, identification of unconformities and associated stratigraphic gaps. The presence of five unconformities allowed for the definition of the main stratigraphic units arranged in a regressive trend: (1) lower Paleocene interval (Danian p.p.) assigned to a deep basin; (2) Eocene interval (lower Ypresian-lower Bartonian p.p.) from a deep basin to an external carbonate-siliceous platform; (3) lower Rupelian-upper Chattian p.p. interval deposited on unstable slope with turbidite channels passing upward to an external siliciclastic platform; (4) Burdigalian p.p. interval from a slope; (5) Langhian-Serravallian p.p. interval from slope to external platform realms. The petrography of the arenites and calcarenites allowed for the identification of the supplies derived from erosion of a recycled orogen (transitional and quartzose subtypes). The clay-mineralogy analysis indicates an unroofing (first erosion of Cretaceous terrains followed by upper Jurassic rocks) always accomplished by erosion of Cenozoic terrains. Several tectofacies checked in some stratigraphic intervals seem to indicate the beginning of deformation of the basement generating gentle folds and first activation of blind thrusts, mainly during the Paleogene. A preorogenic tectonic framework is considered as responseto the generalized tectonic inversion (from extension to compression) as frequently registered in the central-western peri-Mediterranean areas. The large volumes of reworked terrigeneous supply during the latest Oligocene-Miocene p.p. indicates the beginningsof the synorogenic sedimentation (foredeep stage of the basins) controlled by active tectonics.
\end{abstract}


Keywords: El Habt Tectonic Unit; Ouezzane Tectonic Unit; External Rif; tectono-sedimentary evolution; Cenozoic; Morocco

\section{Introduction}

The geology of Morocco [1] in the broad structural context of north-west Africa includes four main chains (Figure 1A): (1) the Pre-Cambrian Anti Atlas and the northern portion of the West African Craton, (2) the Caledonian-Hercynian Moroccan Meseta, (3) the Middle and High intracontinental Atlas, and (4) the Alpine Rif Chain, which record the effects of the Miocene-Quaternary deformation derived from the Maghrebian-Apennine orogenesis. The framework is completed by several main Cenozoic basins.

The Rif Chain (Figure 1B) constitutes the western part of the Maghrebian Chain inf the Western peri-Mediterranean Alpine Orogen (Figure 1C). Itextends northward into the Betic Cordillera (Southern Spain) constituting the Gibraltar Arc. In this Betic-Riffian orogenic belt, three main paleogeographic domains and paleotectonic zones are represented (as in the rest of the Maghrebian chain) by different complex. These units have been recognized for a long time and derive from the deformation of three main paleogeographic domains: internal (nappes from continental margins), intermediate (nappes from the Maghrebian Flysch Basin located on prevalently oceanic crust) and external (Betic and Africa margins).

The Internal Rifian Zones are constituted by strongly deformed Hercynian basement units that together with their carbonate sedimentary cover, were metamorphosed and thrust over the adjacent Meso- and Ceonozoic basinal units during the Alpine orogeny. According to many authors [2-12]; among others) these rocks are derived from the Mesomediterranean Microplate or Alcapeka located between the European and African plates and surrounded by Tethyan oceanic crust $[8,9]$.

The Maghrebian Flysch Basin, and its lateral extension in the Betic Cordillera and the Southern Apennines comprises different tectonic units characterized by Cretaceous-Miocene sedimentary (clayey and clastic) successions deposited on discontinuous deep oceanic crust $([3,4,13]$; among others) thrusted over different external units.

As in other parts of the branches of the Maghrebian chain, the External Rifian Zones (ERZ) consist of a series of cover nappes of different Mesozoic-Cenozoic successions deposited on the continental African Margin. They were thrust over the African Foreland with SW-vergence and have complex internal geological and tectonic structure. The ERZ were subdivided by Suter [14] in Intrarif, Mesorif and Prerif from interland to foreland zones but no agreement currently exists as to the attribution of specific paleogeographic/tectonic subzones or the significance of stratigraphic formations and units. In addition, the paleogeographic origin of different tectonic units has remained controversial, as counts in particular for the so called "Intrarifian origin" units. So, the geological and tectonic evolution of the Rif-Betic chain is not yet fully clarified and requires better constraints on stratigraphic and tectonic subdivisions, as well as integrated stratigraphic and radiometric dating of tectonic events.

The advancement of geological knowledge in this area is not only of significant interest for the study of the Western peri-Mediterranean Alpine Orogen but also for the hydrocarbon exploration in Morocco ([15-20]; and references therein). 


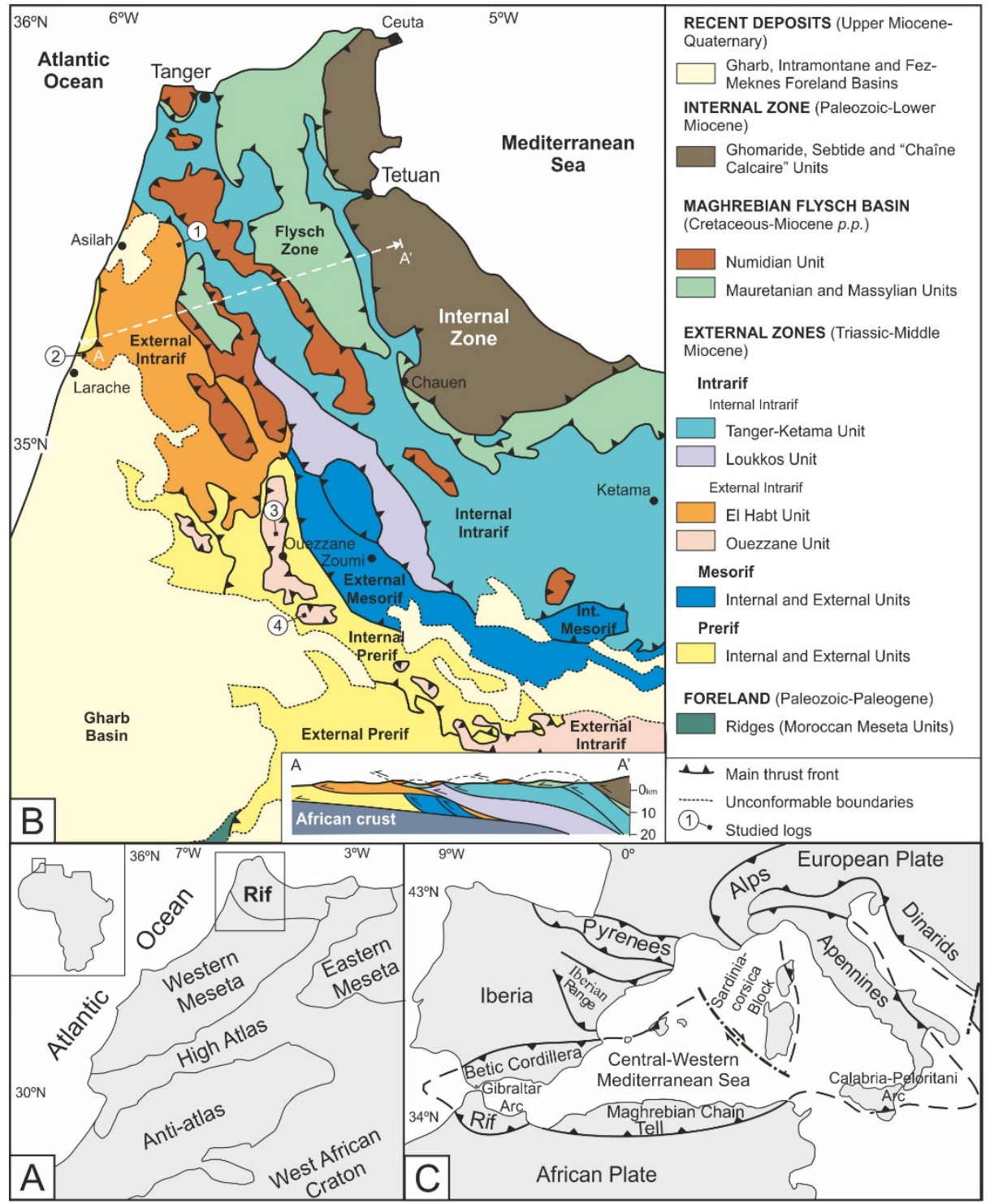

Figure 1. (A) Simplified map of the north-western African area; (B) Simplified tectonic sketch map of the central-western peri-Mediterranean chains (after [11], modified); (C) Geological sketch map of the central-western Rif Chain (after [21], modified).

\section{Geological Setting and Previous Work}

The External Rif Domain (Figure 1C) comprises the sedimentary cover of the North-African passive paleo-margin in contact with the southern Maghrebian Tethyan Ocean branch ([22-24]; among others). This passive margin was affected during the Mesozoic by several phases of sedimentation and subsidence.

Triassic sedimentation produced shallow marine carbonate-evaporitic deposits followed by lower Jurassic platform carbonates, upper Jurassic platform carbonate-detritic deposits and a PaleogeneMiocene thick wedge of shallow to deep marine siliciclastic deposits. Cenozoic sedimentation resulted insignificant lateral variations of lithofacies and thickness associated with frequent synsedimentary tectofacies such as olistostromes and slumps (e.g., [21,23,25-29]; among others). In the northern Rif, several main deformational phases ([21,30]; and references therein) have been recognized: (1) Paleogene folding of the metamorphic basement, (2) folding and thrusting propagating south-southwest during the early-middle Miocene; (3) thrusting and strike-slip faulting from late Miocene to the Quaternary. 
The subdivision of the ERZ in Intrarif, Mesorif and Prerif proposed by Suter [14] has been generally accepted. This author further subdivides the Intrarifian units into: (i) Intrarifian origin nappes and (ii) an Intrarifian Zone comprising from internalto external positions, the Ketama, Internal Tanger, External Tanger andLoukkos Units. These units also show differences on the stratigraphic record Suter [14]. So, the Ketema unit is considered the basement of the Tanger unit showing only Jurassic and Lower Cretaceous rocks with a slight metamorphism sometimes. The Internal Tanger unit is only made of Upper Cretaceous rocks. The External Tanger unit shows Upper Cretaceous rocks (similar to those of the Tanger-Interne) and also Cenocoic rocks. Loukkos is also made of Upper Cretaceous to Cenozoic rocks but representing a shallow marine area while the other units show deep marine environments. However, this approach has created confusion concerning the correlation of the stratigraphic records in different areas of the same subzone because of the use of differentstratigraphic and tectonic criteria by different authors. This problem is further worsened by the fact that units attributed to the Intrarif are: deeply rooted, more or less detached from their original basement (parautochthonous/allochthonous) and affected by superficial gravity-driven tectonics. This ensemble is also affected by two major ENE to NE striking strike-slip faults: the Jebha and Nekor faults related to the westward movement of the Alboran Domain relative to the African and Iberian plates.

So, the Intrarif represents the most internal subzone of the ERZ and it is constituted by various tectono-sedimentary units which are differently defined and interpreted based on different criteria and methodological approaches ([21,27-38]; among others and references therein). Indeed, many authors have mentioned the tectonic complexity of the Intrarif subzone, underlining the existence of multiple nappe units displaced from their original paleogeographic locations and overriding more external subzones. These tectonic translations have obscured original spatial and temporal relationships between stratigraphic successions.

In this way, the Intrarif subzone is subdivided into the Internal and the External Intrarif. The Internal Intrarif comprised the Tanger-Ketama and Loukkos units (para-autochtonous). In turn, the Tanger Unit is further divided into a Cretaceous internal subunit and a Cenozoic external one. The External Intrarif is made of several other unrooted units or tectonic klippen (Aknoul, Tsoul, El Habt, Ouezzane Units, etc.) which are considered to be of Intrarifian origin (e.g., [14]).

The Intrarif subzone has been studied by different authors in the past forty years who have produced new paleogeographic and paleotectonic interpretations ([27,28,30,37,39,40]; among others). Asilah andLarache Sandstones deserve special mention [41]. The Asilah Sandstones have been assigned to the Habt Unit [42-44]. Contrarily, the Larache Sandstones have been assigned to the Ouezzane Unit [45] but seem to be detached from their substratum [25,39,46-51].

Recently, we have previously worked on other sectors of the western External Riffian Zones. In concrete, we have published two papers on the External Tanger Unit [21,38]. Our studies have furnished new stratigraphic, paleogeographicand paleotectonic data on the Cenozoic successions of that sector.

Despite these studies and due to the vastness of the Rif, many problems are still unresolved concerning the ERZ which might also be due to a lack of homogeneous data and poor integration. Main problems arise from the nomenclature mixing stratigraphic and tectonic terms. Other problems are related to the lack of agreement in the original paleogeographic position of the External Intrarif units. Another problem is that recently an oceanic or thinned crust has been proposed for the upper Jurassic-Miocene Mesorif units [52,53]. Moreover, the relationships of the ERZ with the innermost domain, represented by the Maghrebian Flysch Basin (deposited on oceanic crust), are still unknown. In addition, the nature of the basement (oceanic, transitional or continental) of the most Internal Intrarif Zone (Tanger unit) is under discussion. Nevertheless, a general framework of the ERZ is presented by Frizon de Lamotte et al. [23] which can constitute a useful reference. Other stratigraphic reconstructions of the ERZ have been recently addressed to the location of the hydrocarbon reservoir $[17,19,20,54]$. 


\section{Aim and Methods}

This study consists of a better definition of the Cenozoic stratigraphic record and lateral correlations supported by petrographic and mineralogical characterization of the El Habt and Ouezzane Tectonic Units belonging to the Intrarif subzone. This new contribution, and two previous ones [21,38] constitutes a progressive study of the ERZ of our research group.

This research is based on interdisciplinary methodological approach (stratigraphic reconstructions, biostratigraphy dating, mineralogical and petrographic analysis, etc.) of the upper Cretaceous-Cenozoic succession. More in detail, the utilized methodology consists of: (i) field analyses (lithostratigraphic reconstructions and sampling of specific stratigraphic sections and tectonic observations) and (ii) laboratory analysis: biostratigraphy, petrography of arenites, clay mineralogy, also used to improve the stratigraphic interpretation.

Data integration allowed space-time reconstructions of the events including specific objectives such as (i) characterization of the Intrarifian Origin Units; (ii) identification of sedimentary gaps and angular unconformities, sequential stratigraphy, recognition of the main stratigraphic and tectonic events, and, finally, a paleogeographic and paleotectonic reconstruction.

The biostratigraphic study is based on the planktonic foraminifera found in 55 beds ( 9 samples in N Tahar Village section, 7 in Mezgalef, 18 in Douar Ahel Chane and 21 in Oulad Ktir) of marly and clays subjected to the traditional washing and fractionation by sieves of $150 \mu \mathrm{m}$ (main studied fraction) and $125 \mu \mathrm{m}$. The subtropical biozonations established by Berggren et al. [55], Olsson et al. [56], Berggren and Pearson [57,58] and revised by Wade et al. [59] were considered in the Paleogene sediments. The standard zonation of Blow [60] was used for the Neogene. The most significant bioevents of the Mediterranean area [61-63] were used together for the Global Standard Chronostratigraphic Scale [64].

Seven samples were studied in thin section with a polarized-light optical microscopy for a preliminary petrographic characterization. The standard procedures [65-67] were used. The petrographic groups of Zuffa [68,69] consisting of: noncarbonate extrabasinal (NCE); carbonate extrabasinal (CE); non-carbonate intrabasinal $(\mathrm{NCI})$ and carbonate intrabasinal $(\mathrm{Cl})$ were considered and also further internal subdivisions based on criteria proposed by Zuffa [68-70] and Fontana et al. [71]. Following standard procedures, single crystals larger than $0.0625 \mathrm{~mm}$ were counted [66-68].

Preliminary mineralogical analyses on the whole-rock and $<2 \mu \mathrm{m}$ grain-size fraction (clay fraction hereafter) mineralogy of selected 19 samples were performed. The samples were ground and the obtained powders were analyzed by X-ray diffraction (XRD) using a PANalytical X'Pert Pro diffractometer (Cu-K $\alpha$ radiation, $45 \mathrm{kV}, 40 \mathrm{~mA}$ ), equipped with an $X^{\prime}$ Celerator solid-state lineal detector. The diffraction patterns were obtained by a continuous scan from $3^{\circ} 2 \theta$ to $60^{\circ} 2 \theta$, with a $0.01^{\circ}$ $2 \theta$ resolution. The XPOWDER ${ }^{\circledR}$ program [72] was used for semiquantitative mineral composition interpretation of the whole-rock and clay-fraction samples.

For the non-calcareous clay fraction, oriented mounts on glass slides were prepared following standards procedures for expandable clay-mineral identification $[73,74]$. The reflections and reflecting powers of Biscaye [75] and Holtzapffel [73] were used for mineral phases. Based upon the XRD technique, the semiquantitative evaluation of each mineral phase (in weight percent, wt.\% normalized to $100 \%$ ) has an accuracy of $\sim 5 \%$. Replicated analyses of a few selected samples gave a precision of $\pm 3 \%$ $(2 \sigma)$. Some XRD parameters werealso examined following standard procedures smectites [74,76-79]: the intensities ratio of the Qtz(001):Qtz(101) peak areas of quartz (Qtz(001):Qtz(101) ratio hereafter) in the whole-rock XRD diffractograms; the intensities ratio of the Sme(003):Sme(002) peak areas of smectite (Sme(003):Sme(002) ratio hereafter) from ethylene-glycol solvated clay-fraction XRD diffractograms to differentiate dioctahedral and trioctahedral; and the intensities ratio of the Ill(002):Ill(001) peak areas of illite (Ill(002):Ill(001) ratio hereafter) from decomposed air-dried clay-fraction XRD diffractograms to discern authigenic from mature illite. 


\section{Stratigraphy of the El Habt and Ouezzane Nappes}

For each unit, two stratigraphic sections were lithostratigraphically reconstructed (Figure 1C). In each of them, field observations (lateral relationships, internal and external structures of the beds, sampling, etc.) (Figure 2A) together with biochronostratigraphy analyses (Figure 2B) were performed.

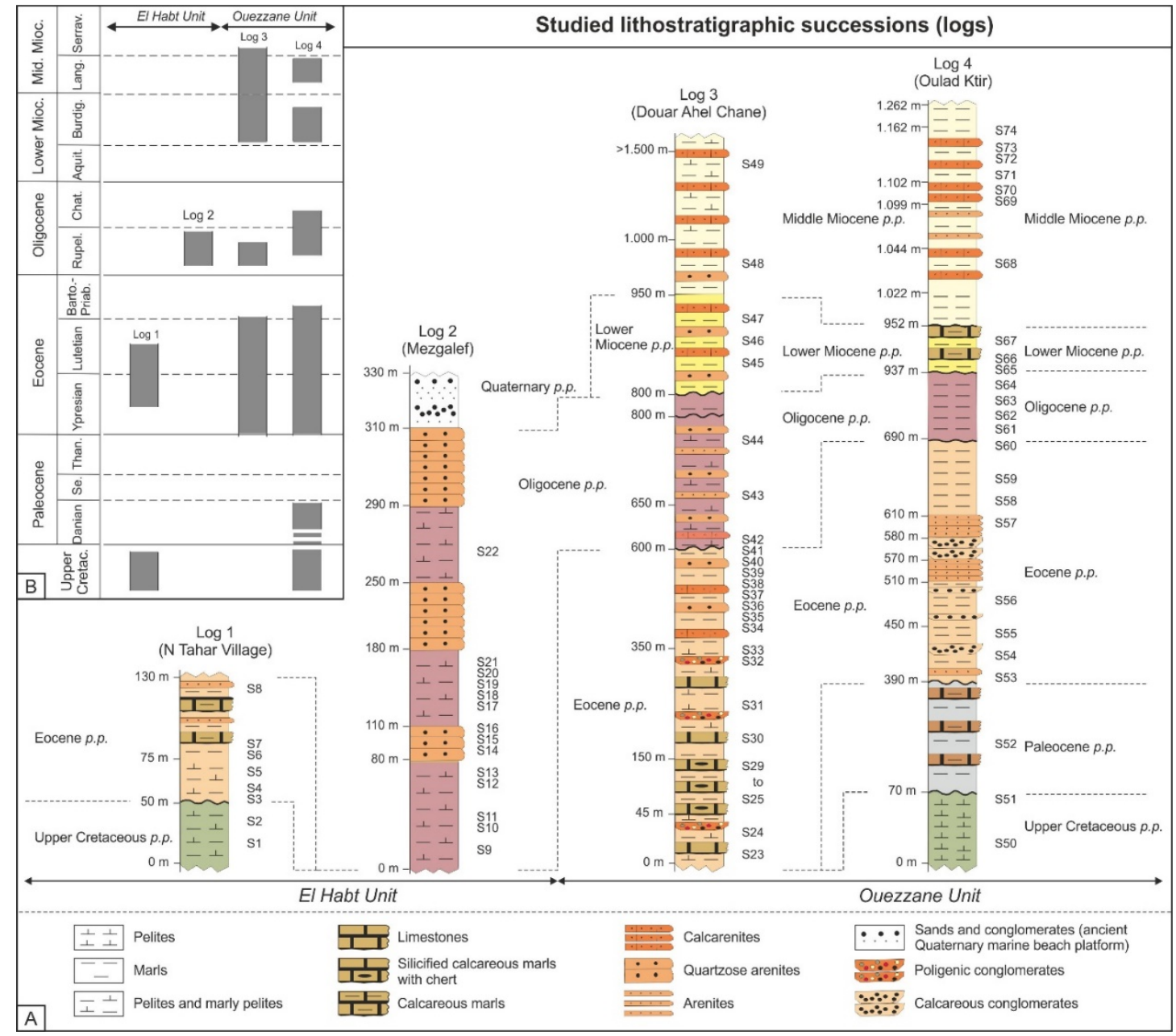

Figure 2. Synthetic litho- and biostratigraphy results of the stratigraphic sections concerning the El Habt and Ouezzane Units. (A) lithostratigraphy of the studied successions (located in Figure 1) and lateral correlations with location of the collected samples; (B) chronostratigraphic range and synthetic chronology of the studied successions.

\subsection{El Habt Tectonic Unit}

The El Habt Unit (External Intrarif Subdomain) consists of a duplex structure in which subunits show a westward displacement. Two logs (Log1, N Tahar Village; and Log 2, Mezgalef) were reconstructed, measured and sampled (Table 1, Figure 2). In this area, the succession of the N Tahar Village is overthrusted by the Mellouse Flysch Nappe and the External Tanger Unit northward. In addition, this last unit thrusts the most Internal Prerif in the NW sector where the Mezgalef log has been studied.

Log 1 (N Tahar Village). The considered succession is about $130 \mathrm{~m}$ thick. It belongs to a monoclinal structure where an unconformity separates different stratigraphic intervals: (i) a Cretaceous substrate made of greenish pelites (samples S1 and S2); (ii) a first interval $75 \mathrm{~m}$ thick of greyish pelites with variable content in marls or sand; (iii) follows a second interval of $55 \mathrm{~m}$ thick of varicoloured pelites, marls, calcareous marls and arenites to the top. The Cretaceous and lower Cenozoic intervals show signs of carbonate dissolution (S3 to S5 samples) as also the radiolarians and rare planktonic 
foraminifers attest in the lower Cenozoic levels. The presence of $A$. soldadoensis, M. subbotinae and $M$. aragonensis (cf. M. lensiformis (Subbotina) foraminifera indicate the E4-E5 zones referable to middle-late Ypresian. Upwardly, some levels of the log (samples S6 and S7) are azoics but in the uppermost one (S8) A. bullbrooki, A. cuneicamerata, I. broedermanni, P. micra and forms similar to T. possagnoensis indicatethe lower-middle Lutetian (E8-E9 zones). The features of this bioassembalge could indicate a deep basin realm.

Table 1. Main field data (units, logs, localities, UTM coordinates, thickness, samples, boundary types, lithofacies and lithological associations) and laboratory results (ages, petrofacies and mineralogical associations). * Classification (NCE/CI/CE) according to Zuffa [68,69]; ** Classification (QFL) according to Dickinson [66]; Zuffa [68] and Ingersoll et al. [67].

\begin{tabular}{|c|c|c|c|c|}
\hline \multicolumn{5}{|c|}{ EL HABT NAPPE (External Intrarif Subdomain) } \\
\hline \multicolumn{5}{|c|}{ Log 1: Nord of the Tahar Village (UTM Coordinates: 30 S/237,475 E/3,918,521 N) } \\
\hline $\begin{array}{l}\text { Thickness } \\
(80 \mathrm{~m})\end{array}$ & $\begin{array}{c}\text { Lithofacies and lithological } \\
\text { associations }\end{array}$ & Age & Samples & $\begin{array}{l}\text { Minero-Petrofacies } \\
\text { Association }\end{array}$ \\
\hline 40 & $\begin{array}{c}\text { yellowish-whitish marls, } \\
\text { calcareous marls, thin arenites }\end{array}$ & Middle-LowerEocene & S7 to S8 & \\
\hline 15 & \multicolumn{4}{|c|}{ Transitional stratigraphic boundary (conformity) } \\
\hline 25 & $\begin{array}{l}\text { greenish and reddish pelites, } \\
\text { marly pelites, silty sandy pelites } \\
\text { and occasional thin arenites }\end{array}$ & $\begin{array}{l}\text { Middle-Lower } \\
\text { Eocene }\end{array}$ & S3 to S6 & \\
\hline & & Unconformity & & \\
\hline 50 & $\begin{array}{l}\text { greenish, reddish pelites, } \\
\text { marly pelites }\end{array}$ & $\begin{array}{l}\text { Uppermost } \\
\text { Cretaceous p.p., } \\
\text { near to the K/T } \\
\text { boundary }\end{array}$ & $\mathrm{S} 1$ to $\mathrm{S} 2$ & \\
\hline \multicolumn{5}{|c|}{ Log 2: Mezgalef (UTM Coordinates:30 S/219,397 E/3,908,369 N) } \\
\hline $\begin{array}{l}\text { Thickness } \\
(>330 \mathrm{~m})\end{array}$ & $\begin{array}{l}\text { Lithofacies and lithological } \\
\text { associations }\end{array}$ & Age & Samples & $\begin{array}{c}\text { Minero-Petrofacies } \\
\text { Association }\end{array}$ \\
\hline$>20$ & $\begin{array}{l}\text { beach deposits with large-scale } \\
\text { cross-lamination }\end{array}$ & Quaternary & - & \\
\hline \multicolumn{5}{|c|}{ Quaternary Unconformity (Paleobeach) } \\
\hline 30 & $\begin{array}{l}\text { amalgamated andlenticular } \\
\text { (channelized) thick arenites }\end{array}$ & - & - & \\
\hline 40 & $\begin{array}{c}\text { brownish pelites, marly pelites, } \\
\text { arenites } \\
\text { withmicroconglomerates }\end{array}$ & - & S22 & \\
\hline 80 & $\begin{array}{l}\text { amalgamated, lenticular thick } \\
\text { quartzose arenites channelized }\end{array}$ & - & - & \\
\hline 70 & $\begin{array}{c}\text { brownish pelites, marlypelites, } \\
\text { quartzose arenites and } \\
\text { microconglomerates }\end{array}$ & MiddleRupelian & $\mathrm{S} 17$ to $\mathrm{S} 21$ & \\
\hline 30 & $\begin{array}{l}\text { amalgamated, lenticular } \\
\text { (channelized) thick quartzose } \\
\text { arenites (Numidian-like) }\end{array}$ & $\begin{array}{c}\text { Lowermost } \\
\text { Oligoceneor older }\end{array}$ & $\mathrm{S} 14$ to $\mathrm{S} 16$ & $\begin{array}{l}\text { Calcarenites, } \\
\text { Terrigenous } \\
\text { Arenites *, } \\
\text { Sublitharenite ** }\end{array}$ \\
\hline 80 & $\begin{array}{c}\text { homogeneous brownish pelites, } \\
\text { marly pelites, silty sandy pelites } \\
\text { with presence of Fe-Mn and } \\
\text { chert nodules }\end{array}$ & $\begin{array}{l}\text { Lowermost } \\
\text { Oligoceneor older }\end{array}$ & S9 to S13 & \\
\hline
\end{tabular}


Table 1. Cont.

\begin{tabular}{|c|c|c|c|c|}
\hline \multicolumn{5}{|c|}{ OUEZZANE NAPPE (External Intrarif Subdomain) } \\
\hline \multicolumn{5}{|c|}{ Log 3: Douar Ahel Chane (UTM Coordinates:30 S/263,677 E/3,863,451 N) } \\
\hline $\begin{array}{l}\text { Thickness } \\
(>1500 \mathrm{~m})\end{array}$ & $\begin{array}{c}\text { Lithofacies and lithological } \\
\text { associations }\end{array}$ & Age & Samples & $\begin{array}{l}\text { Minero-Petrofacies } \\
\text { Association }\end{array}$ \\
\hline$>500$ & $\begin{array}{l}\text { pelites, marly pelite and } \\
\text { occasional calcarenites }\end{array}$ & $\begin{array}{l}\text { Langhian-Lower } \\
\text { Serravallian }\end{array}$ & S49 & \\
\hline 50 & $\begin{array}{l}\text { turbiditic succession: thick } \\
\text { calcarenites, brownish quartzose } \\
\text { arenites, limestones and } \\
\text { calcareous-marls }\end{array}$ & Lower Langhian & S48 & $\begin{array}{c}\mathrm{Ill}+(\mathrm{I}-\mathrm{S}) \pm \text { Sme }+ \\
\mathrm{Kln}+\mathrm{Chl}\end{array}$ \\
\hline \multicolumn{5}{|c|}{ Unconformity (?) } \\
\hline 150 & $\begin{array}{l}\text { turbiditic succession: thick } \\
\text { calcarenites, brownish quartzose } \\
\text { arenites, limestones and } \\
\text { calcareous-marls }\end{array}$ & $\begin{array}{l}\text { Lower-Middle } \\
\text { Burdigalian }\end{array}$ & S45 to S47 & $\begin{array}{c}\mathrm{Ill}+(\mathrm{I}-\mathrm{S}) \pm \mathrm{S} \text { me }+ \\
\mathrm{Kln}+\mathrm{Chl}\end{array}$ \\
\hline \multicolumn{5}{|c|}{ Unconformity (?) } \\
\hline \multirow{2}{*}{200} & $\begin{array}{l}\text { pelites, marly pelites, brownish } \\
\text { quartzose arenites (with Bouma }\end{array}$ & dle & S43 to S44 & $\begin{array}{l}\text { Terrigenous arenite } \\
* \text { Litharenite } * *\end{array}$ \\
\hline & $\begin{array}{l}\text { structures), rare limestones, } \\
\text { calcareous-marls and calcarenites }\end{array}$ & Rupelian (O1-O2) & S42 & $\begin{array}{c}\mathrm{Ill}+\mathrm{Kln} \pm(\mathrm{I}-\mathrm{S})+ \\
\text { Sme + Chl }\end{array}$ \\
\hline \multicolumn{5}{|c|}{ Unconformity (?) } \\
\hline 250 & $\begin{array}{l}\text { greyish marls, calcareous marls, } \\
\text { calcarenites, medium-thick } \\
\text { turbiditic calcarenites and } \\
\text { quartzose arenites, } \\
\text { conglomerates and presence of } \\
\text { chaotic internal structure with } \\
\text { frequent blocks }\end{array}$ & $\begin{array}{l}\text { Middle Lutetian } \\
\text { (E10-E11)-Upper } \\
\text { Eocene }\end{array}$ & S34 to S41 & $\begin{array}{c}\text { Terrigenous arenite } \\
*, \text { Litharenite ** } \\
\text { Ill }+\mathrm{Kln} \pm(\mathrm{I}-\mathrm{S})+ \\
\text { Sme }+ \text { Chl }\end{array}$ \\
\hline 200 & $\begin{array}{l}\text { stratified grey-whitish pelites, } \\
\text { limestones, yellowish marly } \\
\text { limestones, and rare thin } \\
\text { conglomerates }\end{array}$ & $\begin{array}{l}\text { Upper Ypresian } \\
\text { (E6-E7)-Middle } \\
\text { Lutetian (E10-E11) }\end{array}$ & S30 to S33 & $\begin{array}{l}\mathrm{Ill}+\mathrm{Kln} \pm(\mathrm{I}-\mathrm{S})+ \\
\quad \text { Sme }+ \text { Chl }\end{array}$ \\
\hline 105 & $\begin{array}{l}\text { stratified grey-whitish marls, } \\
\text { marly limestones, silicified } \\
\text { siltites with bluish chert lenses }\end{array}$ & $\begin{array}{l}\text { Middle Ypresian } \\
\qquad(\mathrm{E} 4-\mathrm{E} 5)\end{array}$ & S25 to S29 & \multirow[b]{2}{*}{$\begin{array}{c}\mathrm{Ill}+(\mathrm{I}-\mathrm{S}) \pm \text { Sme }+ \\
\mathrm{K} \ln \end{array}$} \\
\hline 45 & $\begin{array}{l}\text { greyish pelites, marly and thin } \\
\text { grey-whitish limestones, } \\
\text { sometime in block, and } \\
\text { conglomerates }\end{array}$ & $\begin{array}{l}\text { Lower-Middle } \\
\text { Ypresian (E3-E4) }\end{array}$ & S23 to S24 & \\
\hline \multicolumn{5}{|c|}{ Log 4: Oulad Ktir (UTM Coordinates: 30 S/273,351 E/3,827,972 N) } \\
\hline $\begin{array}{l}\text { Thickness } \\
(2110 \mathrm{~m})\end{array}$ & $\begin{array}{c}\text { Lithofacies and lithological } \\
\text { associations }\end{array}$ & Age & Samples & $\begin{array}{l}\text { Minero-Petrofacies } \\
\text { Association }\end{array}$ \\
\hline 200 & yellowish marls & \multirow[b]{2}{*}{ UpperLanghian } & - & \\
\hline 50 & $\begin{array}{l}\text { white-yellowish marls, } \\
\text { calcarenites }\end{array}$ & & S71 to S74 & $\begin{array}{l}\text { Terrigeneous } \\
\text { arenite }{ }^{*} \\
\text { Litharenite }^{* *}\end{array}$ \\
\hline
\end{tabular}


Table 1. Cont.

\begin{tabular}{|c|c|c|c|c|}
\hline 10 & & \multirow{5}{*}{ Lower Langhian } & - & \\
\hline 3 & calcarenites, marls & & $\mathrm{S} 69$ to $\mathrm{S} 70$ & $\begin{array}{l}\text { Hybrids arenite }{ }^{*}, \\
\text { Litharenite }\end{array}$ \\
\hline 55 & $\begin{array}{l}\text { arenites and white-yellowish } \\
\text { marls }\end{array}$ & & - & \\
\hline 22 & marls, calcarenites & & & \\
\hline 70 & white-yellowish marls & & - & \\
\hline \multicolumn{5}{|c|}{ Unconformity (?) } \\
\hline 15 & $\begin{array}{l}\text { calcareous marls interstratified } \\
\text { with marly limestones }\end{array}$ & Lower Burdigalian & S65 to S67 & \\
\hline \multicolumn{5}{|c|}{ Unconformity (?) } \\
\hline 247 & yellowish marls & $\begin{array}{l}\text { Middle Rupelian } \\
\text { Lower Chattian }\end{array}$ & S61 to $S 64$ & \\
\hline \multicolumn{5}{|c|}{ Unconformity (?) } \\
\hline 80 & yellowish marls & $\begin{array}{l}\text { Late Lutetian (E10) } \\
\text { to Priabonian } \\
\text { (E14-E15) }\end{array}$ & S58 to S60 & \\
\hline \multicolumn{5}{|c|}{ Stratigraphic contact (conformity) } \\
\hline 30 & $\begin{array}{l}\text { fine-medium amalgamated } \\
\text { arenites with breccias at the } \\
\text { base, rare stratified marls }\end{array}$ & - & S57 & $\begin{array}{l}\text { Terrigenous } \\
\text { arenite } \\
\text { Litharenite }^{* *}\end{array}$ \\
\hline 10 & $\begin{array}{l}\text { well cemented conglomerates } \\
\text { with rounded fine arenitic clasts }\end{array}$ & - & - & \\
\hline 60 & $\begin{array}{c}\text { fine-medium amalgamated } \\
\text { arenite beds with breccias at the } \\
\text { base and rare interbedded well } \\
\text { stratified marls }\end{array}$ & - & - & \\
\hline 40 & $\begin{array}{l}\text { marls with occasional thin } \\
\text { conglomerates intercalations }\end{array}$ & $\begin{array}{l}\text { Lower Lutetian } \\
\text { (late E8-E9) }\end{array}$ & S56 & $\begin{array}{l}\text { marls with } \\
\text { occasional thin } \\
\text { conglomerates } \\
\text { intercalations }\end{array}$ \\
\hline \multicolumn{5}{|c|}{ Stratigraphic contact (conformity) } \\
\hline 60 & $\begin{array}{l}\text { yellowish-grey marls and thin } \\
\text { well stratified fine-grained } \\
\text { arenites, rare thick } \\
\text { conglomerates (polygenic and } \\
\text { cherty clasts) and } \\
\text { calcareous marly }\end{array}$ & $\begin{array}{l}\text { Upper Ypresian } \\
\text { (E5-E6)-Lowermost } \\
\text { Lutetian (E8) }\end{array}$ & S54 to S55 & \\
\hline \multicolumn{5}{|c|}{ Stratigraphic contact (conformity) } \\
\hline 320 & $\begin{array}{l}\text { yellowish-whitish marls with } \\
\text { occasional thin calcareous } \\
\text { marly beds }\end{array}$ & $\begin{array}{l}\text { Lower Paleocene } \\
\text { (P2)-Upper } \\
\text { Paleocene (P4c-P5) }\end{array}$ & S52 to S53 & \\
\hline \multicolumn{5}{|c|}{ Unconformity (?) } \\
\hline 30 & blackish pelites & Late Maastrichtian & S51 & \\
\hline$>40$ & blackish pelites & $\begin{array}{l}\text { Middle-Upper } \\
\text { Maastrichtian }\end{array}$ & S50 & \\
\hline
\end{tabular}

$\log 2$ (Mezgalef). The succession, $330 \mathrm{~m}$ thick, is part of a monoclinal structure where three stratigraphic intervals can be distinguished. To the top, an interval of cross-laminated Quaternary 
sands of beach environment is overcome by means an unconformable surface. The lower interval (80 $\mathrm{m}$ thick) is made of brownish pelites and turbidite beds (arenites with a variable content in marls) with added sands and Fe-Mn and chert nodules. The microfauna is mainly made of agglutinated foraminifera and/or radiolarians. The set of features indicates a deep realm referable to a probable slope/channel. The upper interval consists of channelized and amalgamated lenticular arenites of up to $30 \mathrm{~m}$ thick with occasional calcarenites referrable to a submarine fan. This last interval is followed by $70 \mathrm{~m}$ of brownish pelites with arenites intercalations and of occasional microconglomerate beds (10-30 cm thick). The identification of G. ampliapertura group, G. eocaena group, and P. opima (samples $\mathrm{S} 17$ to S21) in this last interval level indicates middle Rupelian (O2 zone). The succession of this log is arranged into minor depositional cycles with a shallowing trend.

\subsection{Ouezzane Tectonic Unit}

The sedimentary record of the Ouezzane Unit has been reconstructed in Log 3 (Douar Ahel Chane) and Log 4 (Oulad Ktir logs) (Table 1, Figure 2). In this unit the age of the sedimentary record is wider than that of the El Habt Unit since the Paleocene-middle Miocene is well represented and the older stratigraphic beds seem to be pelagic and frequently below the CCD level. This nappe thrusts the Internal Prerif (in both studied logs) while in other sectors thrusts the External Prerif.

Log 3 (Douar Ahel Chane). In this succession, about $1.500 \mathrm{~m}$ thick, seven intervals have been differentiated showing a N-S oriented syncline structure. The lowest interval is represented by $45 \mathrm{~m}$ of greyish pelites with intercalations of thin limestones dated (sample S23) at lower-middle Ypresian (E3-E4) by the presence of $A$. soldadoensis group (including A. angulosa), M. subbotinae group (including M. aequa), and the absence of more modern forms (e.g., groups of A. bulbrooki and M. aragonensis). The next interval (105 $\mathrm{m}$ thick) is made of stratified greyish marly limestones with chert lenses or ribbons and silicified silty or marly beds. It is lower-middle Ypresian age because the foraminifera assemblage is similar to the former (samples S24 to S29). The third interval that follows (200 m thick) is made of greyish pelites and calcareous-marls and rare thin poligenic conglomeratic beds. The lower beds of this interval have been dated (sample S30) as late Ypresian (E6-E7) by the presence of A. gr. bulbrooki and M. gr. Aragonensis and the absence of $A$. gr. soldadoensis and M. gr. subbotinae; while the uppermost beds (sample S34) have been dated as upper Lutetian (E10-E11) by the presence of H. lehneri, H. liebusi and T. pomeroli. The following interval is $50 \mathrm{~m}$ thick and it is made of greyish marls and calcareous marls with turbidite intercalations of calcarenites and arenites (S35: litharenites) where chaotic structures and disarticulated slumps are also present. Despite the shortage of forams in this interval the presence of T. cerroazulensis and the absence of Acarinina could indicate a Bartonian p.p. in age.The Eocene succession indicates deep realms marked upwards by siliceous tubidite beds and slumps. After an unconformity follows $200 \mathrm{~m}$ of a stratified interval of brownish calcareous-marls and thick turbidite (Bouma intevals $\mathrm{T}_{\mathbf{a}-\mathbf{b}}, \mathrm{T}_{\mathbf{a}-\mathbf{b}-\mathbf{c}}, \mathrm{T}_{\mathbf{a}-\mathbf{b}-\mathbf{c}-\mathbf{d}}, \mathrm{T}_{\mathbf{a}-\mathbf{c}}$ ) terrigeneous arenites (S42: litharenites) and calcarenites. This interval (sample S43) shows Oligocene microfauna (Zone O2: middle Rupelian) characterized by the presence of G. ampliapertura, G. increbescens, G. eocaena group (including G. corpulenta) and C. dissimilis, while Eocene typical species as P. micra are absent. Upwards (sample S44) the late Rupelian is dated by the presence of $P$. opima. The above seem to indicate that the unconformity comprises a gap affecting the late Eocene (most part of the Bartonian and the Priabonian) and the lowermost Oligocene (Lower Rupelian). The Oligocene interval seems to belong to slope realms with the presence of diverse turbidite facies.

A new interval, $150 \mathrm{~m}$ thick, is deposited after a new unconformity with a gap comprising the late Oligocene up to the base of the Burdigalian. This interval is made of thick calcarenites, brownish quartzose arenites, limestones and calcareous-marls. The arenites show internal Bouma structures like: $\mathrm{T}_{\mathbf{a}-\mathbf{b}}, \mathrm{T}_{\mathbf{a}-\mathbf{b}-\mathbf{c} \text {, }}$

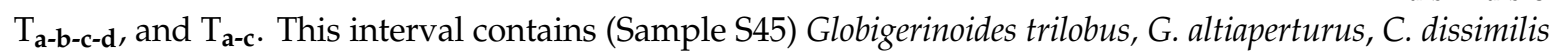
and G. suteri indicating the lower Burdigalian p.p. (lower zone N5) and at the top (Sample S47) the zone N8 (lower Langhian) for the presence of $P$. sicanus. The succession ends with about $550 \mathrm{~m}$ of pelites, marly pelites and occasional calcarenites. At the top (Sample S49), this interval has been dated 
as lower Serravallian by the presence of Orbulina and intermediate morphotypes between G. miozea and G. praemenardii (identified as G. cf. praemenardii). The Miocene portion of the succession marks an environmental regression from a probable slope to external platform.

Log 4 (Oulad Ktir). It shows a succession of $1.262 \mathrm{~m}$ in thickness structured into a NW-SE syncline where different stratigraphic intervals often separated by unconformity have been recognized. The lowest one consists of $70 \mathrm{~m}$ of middle-upper Maastrichtian blackish pelites with the presence of Rosita contuse (Sample S50) and Racemiguembelina fructicosa and Abatomphalus mayaroensis (Sample S51). Similar lithofacies to that of the previous Log 1 have been here recognized indicating a deep realm.

After an angular unconformity, the second interval (320 m thick) is made of yellowish-whitish marls and local calcareous marls. This interval is dated (Sample S52) to Paleocene p.p. (P2 zone) by the presence of P. pseudobulloides, P. uncinata, P. inconstans, and G. compressa and the absence of Acarinina and Morozovella.

After a second unconformity the third interval, $60 \mathrm{~m}$ thick, shows yellowish-grey marls, thin arenites and occasional conglomerates containing polygenic and cherty clasts at the base. The lower portion of this interval is referable to the lower Ypresian (E3 zone; sample S53) for the presence of G. chapmani with Acarinina (A. soldadoensis and A. angulosa) and Morozovella (M. subbotinae and M. aequa). Upwards, this interval reaches the lower Lutetian by the presence of A. bullbrooki, A. cuneicamerata, P. micra, and Globigerinids eocaena and G. corpulenta (Sample S55).

The fourth interval consists of $40 \mathrm{~m}$ of greyish marls with local conglomerates dated (Sample S56) at middle-upper Lutetian by the presence of $M$. crassatus. The following interval is made of $60 \mathrm{~m}$ fine-medium amalgamated and channelized bodies of litharenites (probably indicating a slope environment) containing 5-10 cm of breccias at the base. This last interval is followed by $40 \mathrm{~m}$ of cemented polygenic conglomerates with rounded arenitic clasts (diameter 5-10 cm) and arenites. Upwards $80 \mathrm{~m}$ of yellowish marls appear dated at upper Lutetian-lower Bartonian (E10-E11 zones) by the presence of microfauna of the upper Lutetian (Sample S58) with A. topilensis, M. crassatus, H. dumblei, and Early Bartonian microfauna (samples S59 and S60) with T. cerroazulensis and G. index.

After a new unconformity with a gap comprising the upper Eocene and part of the lower Oligocene, a fifth interval of $247 \mathrm{~m}$ in thickness is made of brownish to cream marls dated at upper Rupelian (S62 and S63 samples) by the disappearance of G. ampliapertura (marker of the O2/O3 zonal boundary) and the occurrence of $\mathrm{G}$. angulisuturalis (O3/O4 zonal boundary of the uppermost Rupelian). Later, the disappearance of the P. opima (O5/O6 boundary, early Chattian) is registered in the sample S64 where G. oecaena group, G. cf. primordius and morphotypes close to G. praebulloides (with supplementary dorsal apertures) appear indicating the late Chattian.

After a new unconformity, a sixth interval (15 m thick) is made of calcareous marls and marly limestones with intercalations of fine-medium amalgamated arenitic beds (with breccias levels of 5-10 cm thick at the base) appears dated as lower Burdigalian (S65 to S67) by the presence of G. altiaperturus, G. trilobus, G. peripheroronda, G. suteri and C. dissimilis and the absence of G. subquadratus. Upwards the same lithofacies follow to the end. This interval is dated (S68 to S72 samples) at Lower Langhian (Zone N8), in the lower part, by the presence of G. bisphaericus, P. sicanus and P. glomerosa, and, in the upper part, as late Langhian (S73 sample) by the presence of Orbulina.

In a similar way to the $\log 3$, the Miocene succession seems to indicate the transition from the slope to the external platform environments.

In short, the El Habt Unit is prevalently characterized by the widespread presence of thick quartzarenites, pelites and marly pelites, while the Ouezzane Unit is characterized by a wider diversity of lithofacies showing immature arenites, calcarenites and poligenic conglomerates. Both successions are affected by many unconformities and biostratigraphic gaps, the meaning of which will be discussed below. 


\section{Petrographic and Mineralogical Analyses}

Seven samples of the most representative arenites from El Habt and Ouezzane Tectonic Units were analyzed (Figure 3A/NCE-CE-CI; Q-F-L) in order to obtain preliminary petrographic data. Three petrofacies are recognized applying the NCE-CE-CI graphic $[68,69]$ : calcarenites (S14), hybrid arenites (S70) and terrigenous arenites (S15, S35, S42, S57 and S72); while applying the Q-F-L graphic [66-68], two petrofacies are recognized: litharenites (S42, S57, S70 and S72) and sublitharenites (S15 and S35). The siliciclastic grains in these last arenites are mainly monocrystalline quartz $(8-65 \%)$ and polycrystalline quartz (1-12\%). Recycled quartz grains, K-feldspar and plagioclase $(<6 \%)$, mica flakes (mainly muscovite) $(<1 \%)$ and heavy minerals (mainly zircon) $(<3 \%)$ are detected in all samples. Glauconite grains $(0.5-3 \%)$ and opaque minerals $(<2 \%)$ are present in most of samples. Lithic carbonatic fragments dominate the lithic population constituting up to $25 \%$ of total grains. Carbonate extrabasinal clasts mainly consist of micrite, biomicrite and biosparite, while the intrabasinal grains are bioclastic such as bivalves of mollusk, echinoderms, bentic foraminifers and red algae. The hybrid arenites show fragments of siliciclastic arenites, shales, siltstones and green-sands.

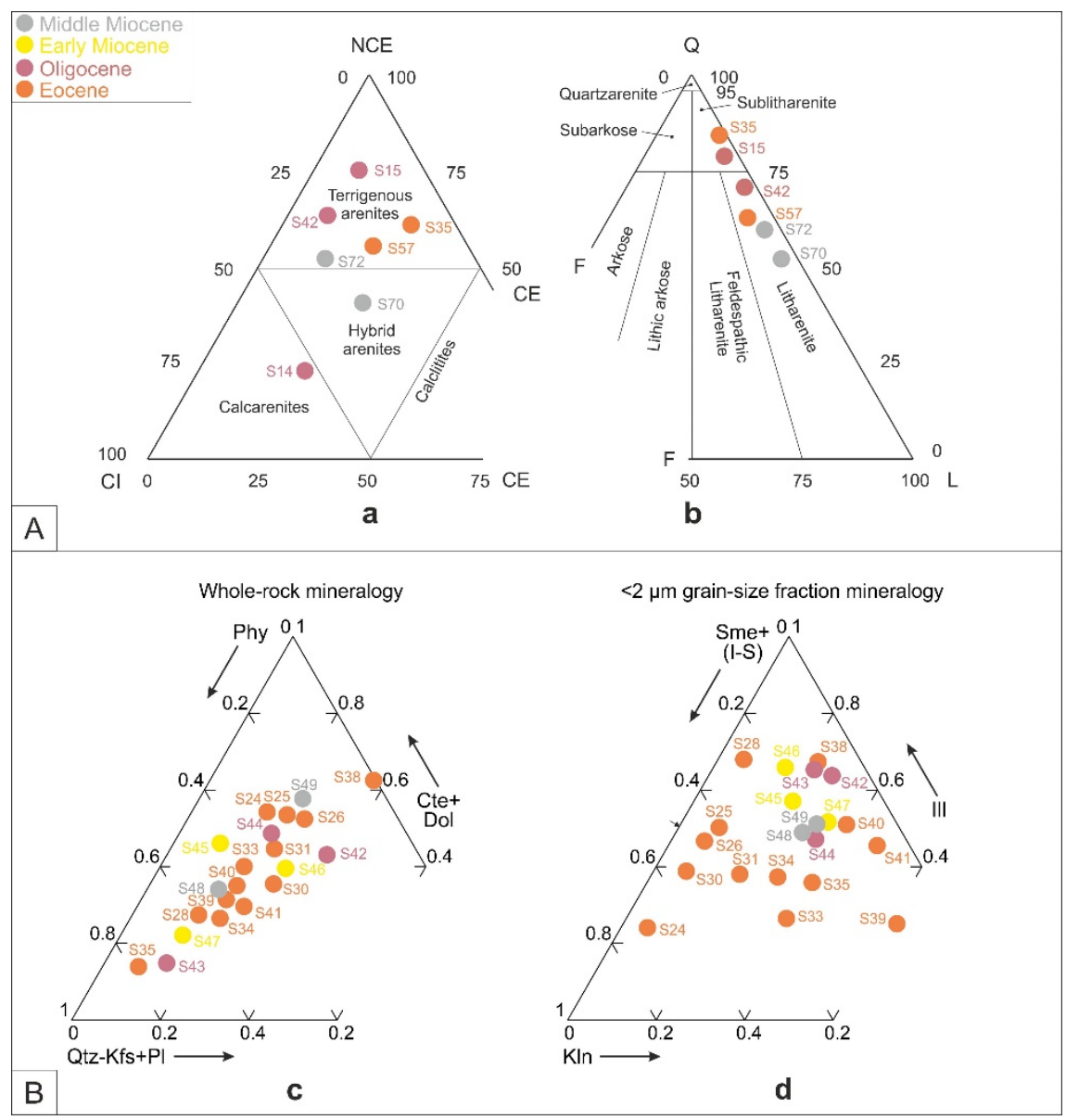

Figure 3. Petrographic and mineralogical composition checked in the arenites clays and marls of the El Habt and Ouezzane Units. (A) Arenite composition: (a) first-order compositional plot where NCE, Non-carbonate Extrabasinal grains; CE, Carbonate Extrabasinal; and CI, Carbonate Intrabasinal; (b) the main composition Q-F-L (Quartz-Feldspar-Lithic frangments including carbonate rocks). (B) Mineralogical results of the whole rock (c) and for the $<2 \mu \mathrm{m}$ grain-size fraction (d).

The mineralogy of the whole-rock and clay fraction was analyzed in 19 samples from the Ouezzane Unit in the DouarAhel Chane log in order to obtain preliminary data (Figure 3B). More in detail, the Eocene portion (S24 to S41, samples) include quartz (5-27\%), phyllosilicates (14-62\%), 
calcite $(5-78 \%)$, dolomite (6-12\%) and minor amounts of K-feldspar, plagioclase, opal CT and clinoptilolite. The clay fraction includes smectite (5-36\%), illite (23-61\%), mixed layer I-S (5-37\%), kaolinite $(5-60 \%)$, chlorite (5-7\%) and palygorskite (5-14\%). The clay-mineral associations consist of Ill $+(\mathrm{I}-\mathrm{S}) \pm \mathrm{Sme}+\mathrm{K} \ln$ for Ypresian and Ill $+\mathrm{Kln} \pm(\mathrm{I}-\mathrm{S})+\mathrm{Sme}+\mathrm{Chl}$ for the Lutetian. The Oligocene portion (S42 to S44, samples) include quartz (5-33\%), phyllosilicates (15-48\%), calcite (21-71\%) and minor amounts of K-feldspar and plagioclase. The clay fraction shows smectite (5-50\%), illite (40-60\%), mixed layer I-S (21-28\%), kaolinite (21-25\%), chlorite (5-8\%)and palygorskite $(<5-7 \%)$. The above data indicates Ill $+\mathrm{Kln} \pm(\mathrm{I}-\mathrm{S})+\mathrm{Sme}+\mathrm{Chl}$ association. The lower-middle Miocene (S45 to 49, samples) are made of quartz (9-23\%), phyllosilicates (23-57\%), calcite (19-61\%) and minor amounts of K-feldspar, plagioclase, opal CT and clinoptilolite. The clay fraction includes smectite (5-7\%), illite (45-61\%), mixed layer I-S (10-14\%), kaolinite (15-31\%), palygorskite (5-8\%) and minor amounts of chlorite. The Ill $+(\mathrm{I}-\mathrm{S}) \pm \mathrm{Sme}+\mathrm{Kln}+\mathrm{Chl}$ clay-mineral association is represented .

\section{Discussion and Interpretations}

The data above exposed allowed some advancement on the Cenozoic tectono-sedimentary evolution, on the sedimentary paleoenvironments and on the source areas of the El Habt and Ouezane subdomains of the ERZ.

\subsection{Tectono-Sedimentary Evolution}

Five main unconformities to which different biostratigraphic gaps associate have been detected (Figure 4). The unconformity boundaries have been located at the base of the older stratigraphic level dated in each depositional sequence.

The oldest unconformity (Unconformity-1) recognized in the Ouezzane Unit (Log 4) shows a gap extending from the uppermost Cretaceous to the Lowermost Paleocene, observable only in the Ouezzane Tectonic Unit $(\log 4)$. The Unconformity-2 is located at the Paleocene-Eocene boundary with a gap affecting the middle Paleocene-lowermost Ypresian and it is recognized in the El Habt Tectonic Unit (Log 1) and in the Ouezzane Unit (Log 4). The Unconformity-3 concerns the Eocene-Oligocene boundary checked only in the Ouezzane Unit (Logs 3 and 4) showing a gap affecting the upper Eocene-lowermost Ruppelian. The Unconformity-4 is also exposed only in the Ouezzane Unit (Logs 3 and 4) with a gap marking the Chattian p.p.-lowermost Burdigalian time span. The youngest unconformity (Unconformity-5) is only restricted at the Burdigalian-Langhian boundary in the Ouezzane Unit (Log 4). This unconformity apparently laterally passes to continuity in the succession of the $\log 3$.

The checked unconformities allow for the division of the stratigraphic record considered into five stratigraphic units with the degree of depositional sequences (Figure 4): (1) lower Paleocene (Danian p.p.) detected only in the Ouezzane Unit ( $\log 4)$ and represented by deep basin paleoenvironments; (2) Eocene p.p. (lower Ypresian-lower Bartonian p.p.) detected in both tectonic units (Logs 1,3 and 4) and represented by deep to slope paleoenvironments; (3) lower Rupelian-lower Chattian p.p. represented in both tectonic units (Logs 2, 3 and 4), whose lithofacies indicate a sedimentation in slope-channel paleoenvironments; (4) Burdigalian p.p. reconstructed in the succession of the Ouezzane Unit (Logs 3 and 4) indicating a slope to external platform paleoenvironments; (5) Langhian-Serravallian p.p. checked in the Ouezzane Unit (Logs 3 and 4) deposited in an external platform. The above exposed indicates a Cenozoic main regressive cycle (from deeper deposits to platform-slope realms).

In the gaps, two portions can be differentiated: the portion below the unconformity boundary and that located above the unconformity (Figure 4). The lowest portion is related to erosion, probably during lowstand intervals (erosional gap), while the uppermost is related to non-deposition over paleogeographic paleorelifs (depositional gap) by means of an onlap device, probably during transgressive intervals. The defined sequences are arranged into transgressive-regressive intervals in which the recorded intervals usually belong to transgressive intervals, while the regressive correspond to the erosive intervals of the gaps. 


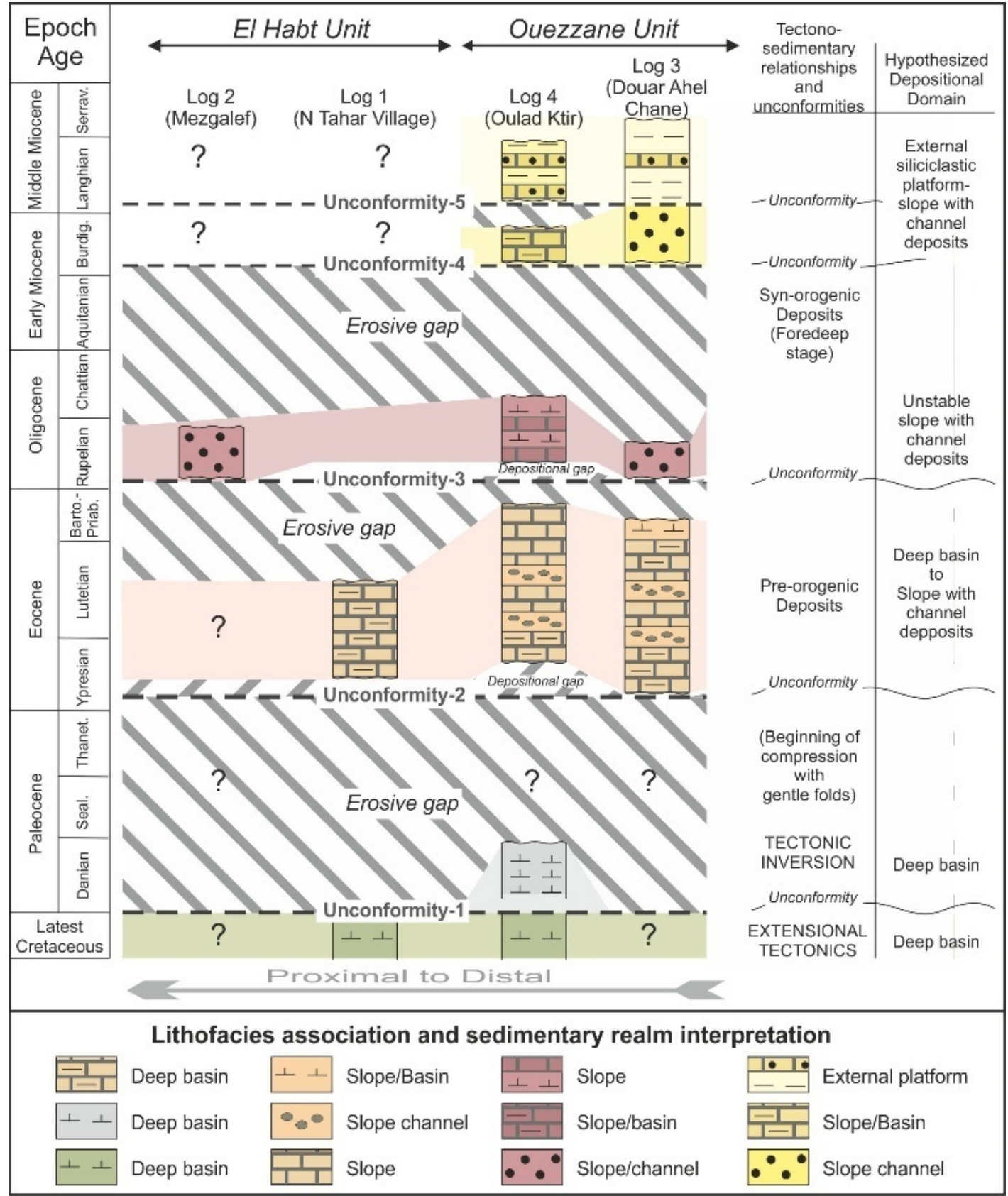

Figure 4. Stratigraphic architecture of the Cenozoic of the El Habt and Ouezzane Units. The arrangement of the studied Logs and correlation with the timetable reflects the supposed paleogeographic position from proximal to distal. In addition, depositional sequences, unconformities, gaps (erosive and depositional), sedimentary realms and tectonic phases are shown.

The proposed stratigraphic architecture clearly indicates a non tabular sedimentation with marked lateral changes as suggested by lateral variation of the: lithofacies, thicknesses, and diachronous stratigraphic boundaries.

According to regional data [8-12,80], after the Cretaceous a paleogeographic reorganization of the external basins of the African Margin took place as a consequence of the beginning of the tectonic inversion (from extensional to compressional) between Europe and Africa plates. In short, this structuring is related to the neo-Alpine phase (Pyrenean of [81]) as response to the beginning of the Africa/Europe convergence during the Eocene and Oligocene. This reorganization would have caused modifications recorded in the stratigraphic framework as unconformities and lateral variations. 
In addition, across the Eocene-Oligocene boundary, the occurrence of the well-known sea level fall in the entire globe due to a climatic cooling caused a generalized regression everywhere. The beginning of convergence (prenappe tectonics) is characterized by differential basement uplift that generated mild folds (also reflected on surface) and initiated blind thrusts leading to the end of the preorogenic sedimentation in the central-western Mediterranean area [80,82-84]. The beginning of the large and growing volumes of reworked terrigeneous supply (turbidites, slumps, olistostromes, etc.) from the latest Oligocene and during the Miocene p.p. indicates the starts of the synorogenic sedimentation (foredeep stage of the basins) controlled by active tectonics contemporary to the sedimentary processes.

\subsection{Supply Origin}

Modal analyses of arenites indicate an origin from "recycled orogen" tectonic setting [85] with a trend from Paleogene to Miocene from the quartzose recycled to the transitional recycled (Figure 5). Recycled quartz grains (second-cycle) together with frequent fragments of sedimentary rock are probably due to the erosion of older siliciclastic and carbonate formations. The abundance of recycled monocrystalline quartz, the shortage of feldspars, micas (unstable minerals) and the presence of zircon (ultra-stable minerals) indicate a multicyclic origin derived very probably from the African craton in tune with paleogeographic position of the basins.

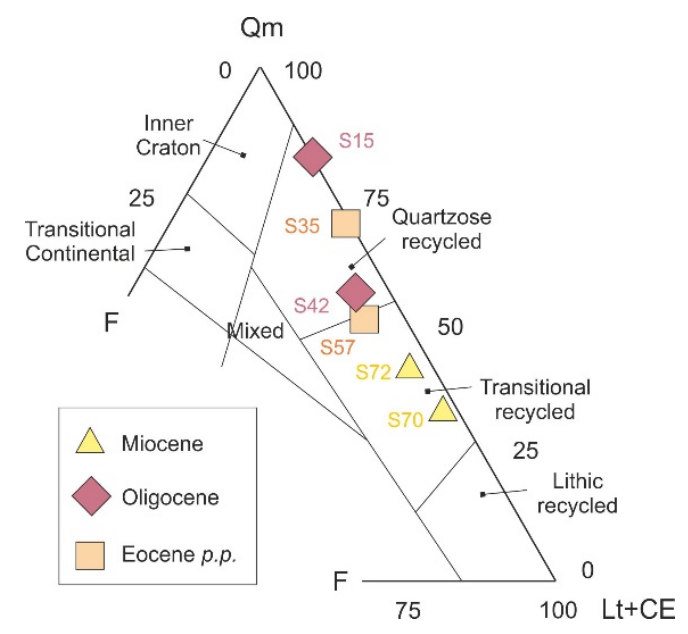

Figure 5. Qm/F/Lt + CE ternary diagram [85] indicating a discrimination of the sandstones' provenance. Qm: monocrystalline quartz; F: feldspars (plagioclase and K-feldspars); Lt + CE: lithic fragments including carbonate extrabasinal clasts.

The clay-mineral associations indicate source areas for the Mesozoic-Cenozoic considered successions of the ERZ as follows: (1) Ill+Chl \pm Kln for upper Jurassic and lower Cretaceous marine formations ([86,87]); (2) Ill + Kln $\pm($ I-S) + Sme and Ill + (I-S) \pm Sme + Kln for Albian-Cenomanian marine formations; and (3) Ill + (I-S) \pm Sme (in: Maaté et al., 2017 [21]) and Ill + Sme $\pm(I-S)+$ $\mathrm{K} \ln [88]$ for late Cretaceous and Paleogene marine formations, respectively. The Ill + (I-S) \pm Sme + Kln clay-mineral association identified in the Eocene and Oligocene deposits might come from a mixing from Albian-Cenomanian to Paleocene terrains, while the Ill $+(\mathrm{I}-\mathrm{S}) \pm \mathrm{Sme}+\mathrm{Kln}+\mathrm{Chl}$ clay-mineral association identified in the Burdigalian deposits might derive from a mixing from upper Jurassic to Paleocene terrains. The source-area history described suggests a complex erosional evolution since deposits were initially fed by Paleogene and Cretaceous terrains; upper Jurassic to Paleocene terrains, later.

\subsection{Correlations with Regional Tectonic Phases and Deformation}

Several papers have been published in the last two decades in the Betic, Rifian and Tellian External Zones proposing tectonic phases associated to unconformities recognized in the Cenozoic 
sedimentation $[10,21,83,84,89-94]$. The papers from Khomsi et al. [83,88] presented structural interpretations on seismic reflection sections, as well as seismic sequential analysis in the Paleogene of the eastern Tunisian Tell. In concrete, these authors mentioned a D5 unconformity (Eocene-Oligocene boundary in age) correlatable with our Unconformity-3. According to these authors this tectonic phase should be associated to a flexuration in the front of the Atlas ("Atlas event"). This Eocene-Oligocene boundary was also mentioned by Belayouni et al. [91] also in the Tunissian Tell, by Guerrera et al. [83], Guerrera et al., [84] in the External Betic Cordillera, and Maaté et al.) [21] in the Intrarif of the External Riffian Zone. These last authors also recognized an unconformity Cretaceous-Paleocene boundary in age correlatable with our Unconformity-1.

In the case of the Miocene interval, several works pointed out Miocene unconformities associated to tectonic phases. In the Internal Rif Zone $[93,94]$ by means of a structural analysis study recognized their D2 and D3 compressive phases correlables with our Unconformity-4 and Unconformity-5. Similar Miocene tectonic phases has also been detected in the Tunisian Tell [92], the External Betic Zone [10,84], and the Intrarif of the External Riffian Zone [21]. All of the above suggests a common regional tectonic cadre at western Mediterranean scale probably related to the Africa-Iberia-Europe plate motion.

The source area of the studied succession is correlated with a "recycled orogen" with a trend from Paleogene to Miocene from the quartzose recycled to the transitional recycled. A multicyclic origin derived very probably from the African craton and more in detail of the Atlas Zone is evoked. The few deformational and exhumation data of the Atlas Zone indicate rising from the Triassic onwards [24,95]. In detail, the emersion of the Atlas Zone is supposed at the end of the Cretaceous with a rapid rising in Miocene times due to the thrusting of the High and Middle Atlas over the more external areas [24].

\section{Conclusions}

1. Five unconformities with associate gaps were detected. The Unconformity-1, only recognized in the Ouezzane Unit, has a gap affecting the uppermost Cretaceous to the Lowermost Paleocene. The Unconformity-2, recognized in both tectonic units, is located at the Paleocene-Eocene boundary with a gap affecting the middle Paleocene-lowermost Ypresian. The Unconformity-3, only visible in the Ouezzane Unit, appears at the Eocene-Oligocene boundary with a gap affecting the upper Eocene-lowermost Ruppelian. The Unconformity-4 is also only exposed in the Ouezzane Unit and has a gap marking the time span Chattian p.p.-lowermost Burdigalian. The Unconformity- 5 is very reduced and only restricted at the Burdigalian-Langhian boundary in the Ouezzane Unit passing laterally to continuity.

2. On the basis of recognized unconformities, the following main stratigraphic units with range of depositional sequence were proposed: (1) lower Paleocene (Danian p.p.); (2) Eocene (lower Ypresian-lower Bartonian p.p.); (3) lower Rupelian-upper Chattian p.p. (4) Burdigalian p.p.; (5) Langhian-Serravallian p.p.

3. On the basis of lithofacies features, fossils association and minerals distribution some generic reconstruction of the sedimentary realms can be proposed: (i) the upper Cretaceous-lower Paleocene succession was assigned to a deep basin; (ii) the lower Eocene p.p.-upper Eocene p.p. to a deep basin to external carbonate-siliceous platform; (iii) the Oligocene p.p. sequence was deposited on unstable slope with turbidite channels passing upward to an external siliciclastic platform; (iv) the two upper depositional sequences (Burdigalian to Serravallian period) indicate the upward transition from slope to external platform.

4. The sequences are arranged into transgressive-regressive intervals where the deposits are related to the transgressive interval; meanwhile, the gaps are interpreted as erosive periods due to regressions. The whole Cenozoic sedimentation represents a major regressive cycle. Climate driven sea-level changes are only modest $(\approx 100 \mathrm{~m})$ and do not offer a satisfactory interpretation for alternating erosive and depositional stages spanning millions of years each. Therefore, these must reflect alternating tectonic uplift and subsidence due to a regional tectonics at western Mediterranean scale, probably related to the Africa-lberia-Europe plate motion. 
5. The petrographic preliminary study allows proposing a source area belonging to rocks deriving from "recycled orogen" (transitional recycled and quartzose recycled subtypes). The clay-mineralogy preliminary study indicates a complex unroofing with erosion of Cenozoic terrains in the whole period accomplished by Cretaceous terrains erosion, first, followed by upper Jurassic erosion later. An Atlas origin is evoked for these terrigenous supplies.

6. The study area was affected by a prenappe tectonics resulting in blind thrusts and growth folds during the Paleogene after the generalized tectonic inversion (from extension to compression) in the Perimediterranean area. After the Alpine extensional phase, the Paleogene tectonic evolution (after the tectonic inversion to compression) can be correlated with a prenappe compressional tectonics consisting of gentle deformation prevalently resulting in a Mesozoic substrate growing folds and blind thrusts. This evolution predated the Miocene nappe tectonics and it is recognized the whole Central-Western Mediterranean Chains. Both Paleogene and Miocene tectonic phases have been also recognized in other sectors of the Rif, in the Tunisian Tell and in the External Betic Cordillera.

7. The beginning of the large and growing volumes of reworked terrigeneous supply (turbidites, slumps, olistostromes, etc.) during the latest Oligocene and the Miocene p.p. indicates the starts of the synorogenic sedimentation (foredeep stage of the basins) controlled by active tectonics during the sedimentary processes

Author Contributions: Field works by M.M.-M., F.G., R.H., A.M., S.M. and F.J.A.; Laboratory analyses by S.M., F.S., J.C.C. and F.J.A.; Cabinet works and performing of the manuscript, figures and tables by M.M.-M., F.G., R.H., A.M., S.M., M.T., F.S., J.C.C., F.J.A., D.P. All authors have read and agreed to the published version of the manuscript.

Funding: Research Project CGL2016-75679-P (Spanish Ministry of Education and Science); Research Groups, Projects of the Generalitat Valenciana, Alicante University (CTMA-IGA); Grants from the University of Urbino Carlo Bo (M. Tramontana).

Acknowledgments: Authors wish to acknowledge the revision performed by three anonymous reviewers.

Conflicts of Interest: The authors declare no conflict of interest.

\section{References}

1. Michard, A.; Frizon de Lamotte, D.; Liégeois, J.-P.; Saddiqi, O.; Chalouan, A. Conclusion: Continental Evolution in Western Maghreb. In Lecture Notes in Earth Sciences; Michard, A., Saddiqi, O., Chalouan, A., Frizon de Lamotte, D., Eds.; Springer Science and Business Media LLC: Berlin/Heidelberg, Germany, 2008; Volume 116, pp. 395-404.

2. Doglioni, C. Main differences between thrust belts. Terra Nova 1992, 4, 152-164. [CrossRef]

3. Guerrera, F.; Martin-Algarra, A.; Perrone, V. Late Oligocene-Miocene syn-/-late-orogenic successions in Western and Central Mediterranean Chains from the Betic Cordillera to the Southern Apennines. Terra Nova 1993, 5, 525-544. [CrossRef]

4. Guerrera, F.; Martín-Martín, M.; Perrone, V.; Tramontana, M. Tectono-sedimentary evolution of the southern branch of the Western Tethys (Magrebian Flysch Basin and Lucanian Ocean). Terra Nova 2005, 17, 358-367. [CrossRef]

5. Doglioni, C.; Mongelli, F.; Pialli, G. Boudinage of the Alpine belt in the Apenninic back-arc. Mem. Soc. Geol. Ital. 1998, 52, 457-468.

6. Doglioni, C.; Fernandez, M.; Gueguen, E.; Sabat, F. On the interference between the early Apennines-Maghrebides back-arc extension and the Alps-Betics orogen in the Neogene geodynamics of the Western Mediterranean. Boll. Soc. Geol. Ital. 1999, 118, 75-89.

7. Guerrera, F.; Martín-Martín, M. Geodynamic events reconstructed in the Betic, Maghrebian, and Apennine chains (central-western Tethys). Bull. Soc. Geol. Fr. 2014, 185, 329-341. [CrossRef]

8. Critelli, S.; Muto, F.; Perri, F.; Tripodi, V. Interpreting provenance relations from sandstone detrital modes, southern Italy foreland region: Stratigraphic record of the Miocene tectonic evolution. Mar. Petrol. Geol. 2017, 87, 2-14. [CrossRef] 
9. Guerrera, F.; Manuel Martín-Martín, M.; Tramontana, M. Evolutionary geological models of the Central-Western Peri-Mediterranean chains: A review. Intern. Geol. Rev. 2019, 1-12. [CrossRef]

10. Martín-Martín, M.; Guerrera, F.; Rodriguez-Estrella, T.; Serrano, F.; Alcalà, F.J.; Raffaelli, G.; Tramontana, M. Miocene tectono-sedimentary evolution of the eastern external Betic Cordillera (Spain). Geodin. Acta 2018, 30, 265-285. [CrossRef]

11. Martín-Martín, M.; Guerrera, F.; Tramontana, M. Geodynamic implications of the latest Chattian-Langhian central-western Mediterranean volcano-sedimentary event: A review. J. Geol. 2020, 128, 706262. [CrossRef]

12. Martín-Martín, M.; Guerrera, F.; Miclaus, C.; Tosquella, J.; Tramontana, M. Paleocene-Lower Eocene carbonate platforms of westernmost Tethys. Sediment. Geol. 2020, 404, 105674. [CrossRef]

13. Durand Delga, M.; Rossi, P.; Olivier, P.; Puglisi, D. Situation structurale et nature ophiolitique des roches basiques jurassiques associées aux flysch maghrébins du Rif (Maroc) et de Sicile (Italie). Comptes Rendus Acad. Sci. Paris 2000, 331, 29-38. [CrossRef]

14. Carte Géologique du Rif, 1/500,000. Available online: https://www.researchgate.net/figure/Carte-Geologiquedu-Rif-Suter-1980-and-Chalouan-et-al-2001_fig1_340023318 (accessed on 12 November 2020).

15. Kuhnt, W.; Chellai, H.; Holhoum, A.; Luderer, F.; Thurow, J.; Wagner, I.; El Albani, A.; Beckmann, B.; Herbin, J.P.; Kawamura, H.; et al. Morocco Basins's sedimentary record may provide correlation for Cretaceous paleoceanographic event worldwide. EOS 1990, 82, 361-364. [CrossRef]

16. Kolonic, S.; Sinninghé Damsté, J.S.; Böttcher, M.E.; Kuypers, M.M.M.; Kuhnt, W.; Beckmann, B.; Scheeder, G.; Wagner, T. Geochemical characterization of Cenomano/Turonian Black shales from the Tarfaya Basin (SW Morocco). Relationships between paleoenvironmental conditions and early sulphurization of sedimentary organic matter. J. Pet. Geol. 2002, 25, 325-350. [CrossRef]

17. Lüning, S.; Adamson, K.; Craig, J. Frasnian organic-rich shales in North Africa: Regional distribution and depositional model. Geol. Soc. Lond. Spéc. Publ. 2003, 207, 165-184. [CrossRef]

18. Sachse, V.F.; Kittke, R.; Heim, S.; Kluth, O.; Schober, J.; Boutib, L.; Jabour, H.; Perssen, F.; Sindern, S. Petroleum source rocks of the Tarfaya Basin and adjacent areas, Morocco. Org. Geochem. 2011, 42, 209-227. [CrossRef]

19. Groune, K.; Halim, M.; Benmakhlouf, M.; Arsalane, S.; Lemée, L.; Amblés, A. Organic geochemical and mineralogical characterization of the Moroccan Rif bituminous rocks. J. Mater. Environ. Sci. 2013, 4, 472-481.

20. Groune, K.; Halim, M.; Arsalane, S. Thermal and mineralogical studies of Moroccan Rif bituminous rocks. Oil Shale 2013, 30, 536-549. [CrossRef]

21. Maaté, S.; Alcalá, F.J.; Guerrera, F.; Hlila, R.; Maaté, A.; Martín-Martín, M.; Raffaelli, G.; Serrano, F.; Tramontana, M. The External Tanger Unit (Intrarif sub-Domain, External Rifian Zones, Morocco): An interdisciplinary study. Arab. J. Geosci. 2017, 10, 556. [CrossRef]

22. Chalouan, A.; Michard, A. The Alpine rif belt (Morocco): A case of mountain building in a subduction-subduction-transform fault triple junction. Pure Appl. Geophys. 2004, 161, 489-519. [CrossRef]

23. Frizon de Lamotte, D.; Zaghloul, M.N.; Faouziya, H.; Mohn, G.; Leprêtre, R.; Gimeno-Vives, O.; Atouabat, A.; El Mourabet, M.; Abass, A. Rif externe: Comment comprendre et expliquer le chaos apparent? Géologues 2017, 194, 13-15.

24. Michard, A.; Saddiqi, O.; Missenard, Y.; Oukassou, M.; Barbarand, J. Les grandes regions géologique du Maroc; diversité et soulèvement d'ensemble. Géologues 2017, 194, 4-12.

25. Lespinasse, P. Géologie des Zones Externs et des Flyschs Entre Chaouen et Zoumi (Centre de la Chaine Rifaine, Maroc); Université Pierre et Marie Curie-Paris VI: Toulouse, France, 1975; p. 248.

26. Asebriy, L. Evolution Tectonique et Métamorphique du Rif Central (Maroc): Definition du Domaine Subrifain. Ph.D. Thesis, Université Mohammed V, Rabat, Morocco, 1994; p. 283.

27. Asebriy, L.; de Luca, P.; Bourgois, J.; Chotin, P. Resédimentation d'âge sénonien dans le Rif central (Maroc): Conséquences sur les divisions paléogéographiques et structurales de la chaîne. J. Afr. Earth Sci. 1987, 6, 917.

28. Tejera de Leon, J.; Duée, G. Relationships between the Neogene foredeep basins of the Western external Rifian belt related to the Arbaoua-Jebha transform fault. Consequences for the interpretation of the evolution of the Rifian belt (Morocco). Trav. Inst. Sci. Rabat Sér. Géol. Géogr. Phys. 2003, 21, 1-19.

29. Zaghloul, M.N.; Di Staso, A.; Gigliuto, L.G.; Maniscalco, R.; Puglisi, D. Stratigraphy and provenance of Lower and Middle Miocene strata within the External Tanger Unit (Intra-Rif sub-Domain, External Domain; Rif, Morocco): First evidence. Geol. Carpathica 2005, 56, 517-530. 
30. Azdimousa, A.; Bourgois, J.; Poupeau, G.; Montigny, R. Histoire thermique du massif de Kétema (Maroc): Sa place en Afrique du Nord et dans les Cordillères bétiques. Comptes Rendus Acad. Sci. Paris 1998, 326, 847-853.

31. Azdimousa, A.; Jabaloy, A.; Asebriy, L.; Booth-Rea, G.; González-Lodeiro, F.; Bourgois, J. Lithostratigraphy and structure of the Temsamane Unit (Eastern External Rif, Morocco). Rev. Soc. Geol. Esp. 2007, 20, 119-132.

32. El Mrihi, A. Structures Alpines des Zones Externes et des Nappes de Flyschs à l'ouest de la Chaîne du Haouz (Rif Septentrional, Maroc). Ph. D. Thesis, Université Mohammed V, Rabat, Morocco, 1995; p. 149.

33. Chaouni, A. Apport des Données Landsat MSS, Radar ERS1-SAR, Modèles Numériques de Terrain à la Compréhension de la Cinématique des Principales Failles de la Péninsule de Tanger Depuis l'Oligocène Supérieur jusqu'à l'Actuel (Rif Septentrional, Maroc). Ph. D. Thesis, Université Mohammed V, Rabat, Morocco, 1996; p. 295.

34. Bargach, K.; Ruano, P.; Chabli, A.; Galindo-Zaldivar, J.; Chalouan, A.; Jabaloy, A.; Akil, M.; Ahmamou, M.; Sanz de Galdeano, C.; Benmakhlouf, M. Recent tectonic deformations and stresses in the frontal part of the Rif Cordillera and the Saïss Basin (Fes and Rabat regions, Morocco). Pure Appl. Geophys. 2004, 161, 521-540. [CrossRef]

35. Chalouan, A.; Michard, A.; El Kadiri, K.H.; Frizon de Lamotte, D.; Soto, J.I.; Saddiqi, O. Continental evolution: The geology of Morocco. Springer-Verlag Berlin Heidelberg. Lect Notes Earth Sci. 2008, 116, 203-302. [CrossRef]

36. Vázquez, M.; Asebriy, L.; Azdimousa, A.; Jabaloy, A.; Booth-Rea, G.; Barbero, L.; Mellini, M.; González-Lodeiro, F. Evidence of extensional metamorphism associated to Cretaceous rifting of the North-Maghrebian passive margin: The Tanger-Ketama unit (external Rif, northern Morocco). Geol. Acta 2013, 11, 277-293.

37. Jabaloy-Sánchez, A.; Azdimousa, A.; Booth-Rea, G.; Asebriy, L.; Vázquez-Vílchez, M.; Martínez-Martínez,J.M.; Gabites, J. The structure of the Temsamane fold-and-thrust stack (eastern Rif, Morocco): Evolution of a transpressional orogenic wedge. Tectonophysics 2015, 663, 150-176. [CrossRef]

38. Maaté, S.; Guerrera, F.; Hlila, R.; Maaté, A.; Martín-Martín, M.; Tramontana, M. New structural data on Tertiary of the External Tanger Unit (Intrarif, Morocco). Geogaceta 2018, 63, 123-126.

39. Zakir, A.; Chalouan, A.; Feinberg, H. Evolution tectono-seédimentaire d'un domaine d'avant-cha^ıne: Exemple des bassin d'El-Habt et de Sidi Mrayt, Rif externe nord-occidental (Maroc); précisions stratigraphiques et modélisation tectonique. Bull. Soc. Géol. Fr. 2004, 175, 383-397. [CrossRef]

40. El Kadiri, K.H.; Hlila, R.; Sanz de Galdeano, C.; López-Garrido, A.C.; Chalouan, A.; Serrano, F.; Bahmad, A.; Guerra-Merchán, A.; Liemlahi, H. Regional correlations across the Internides-Externides front (northwestern Rif Belt, Morocco) during thr Late Cretaceous-Early Burdigalian times: Palaeogeographical and palaeotectonic implications. In Tectonics of the Western Mediterranean and North Africa; Moratti, G., Chalouan, A., Eds.; Geological Society, Special Publications: London, UK, 2006; Volume 262, pp. 193-215.

41. Didon, J.; Hoyez, B. Les séries à faciès mixtes, numidien et gréso-micacé, dans le Rif occidental (Maroc). C. $R$. Somm. Soc. Géol. Fr. 1978, 6, 304-307.

42. Suter, G.; Fiechter, G. Le Rif méridional atlantique (Maroc): Aperçu structural sur la région Ouezzane-Zourni et le pays du Habt (Larache). Notes Mém. Serv. Géol. Maroc. 1966, 26, 15-20.

43. Critelli, S. Provenienza Delle Torbiditi Oligo-Mioceniche del Dominio Esterno e Della Falda Numidica del Rif (Marocco Nord-Occidentale). Ph.D. Thesis, Università della Calabria, Rende, Italy, 1984; p. 128.

44. Cazzola, C.; Critelli, S. Litostratigrafia e petrografia delle quarzareniti torbiditiche oligomioceniche di Asilah (catena del Rif, Marocco Nord-Occidentale). Mineral. Petrogr. Acta 1986, 30, 203-226.

45. Wildi, W. La chaîne tello-rifaine (Algérie, Maroc, Tunisie): Structure, stratigraphie et évolution du Trias au Miocène. Rev. Géol. Dyn. Géogr. Phys. 1983, 24, 201-297.

46. Hottinger, L.; Suter, G. La structure de la zone prérifaine au Sud du Moyen Ouerrha. Comptes Rendus Acad. Sc. Paris 1962, 254, 140-142.

47. Durand Delga, M. La courbure de Gibraltar, extrémité occidentale des chaînes alpines, unit l'Europe et 1'Afrique. Eclogae Geol. Helv. 1972, 65, 267-278.

48. Ben Yaïch, A. Evolution Tectono-Sédimentaire du Rif Externe Centro-Occidental (Régions de M'Sila et Ouezzane, Maroc). La Marge Africaine du Jurassique au Crétacé Inférieur. Les Bassins Néogènes D’avant-Fosse. Ph.D. Thesis, Unitversité Paul Sabatier, Toulouse, France, 1991; p. 308. 
49. Frizon De Lamotte, D.; Andrieux, J.; Guezou, J.C. Cinématique deschevauchements néogènes dans l'Arc bético-rifain: Discussion sur les modèles géodynamiques. Bull. Soc Géol Fr. 1991, 162, 611-626. [CrossRef]

50. Tejera De Leon, J. Les Bassins Néogènes d'avant-Pays du Rif Occidental Liés à la Transformante Jebha-Arbaoua (Maroc). Ph.D. Thesis, Thèse d'Etat es-Sciences, Université De Pau et des Pays de l'Adour, Pyrénées-Atlantiques, France, 1993; p. 323.

51. Chalouan, A.; Michard, A.; Feinberg, H.; Montigny, R.; Saddiqi, O. The Rif Mountain Building (Morocco): A New Tectonic Scenario. Bull. Soc. Géol. Fr. 2001, 172, 603-616. [CrossRef]

52. Michard, A.; Feinberg, H.; Elazzab, D.; Bouybaouene, M.; Saddiqi, O. A serpentinite ridge in a collisional paleomargin setting: The Beni Malek massif, External Rif, Morocco. Earth Planet. Sci. Lett. 1992, 113, 435-442. [CrossRef]

53. Michard, A.; Frizon De Lamotte, D.; Negro, F. Serpentinite slivers and metamorphism in the External Maghrebides: Arguments for an intracontinental suture in the African paleomargin (Morocco, Algeria). Rev. Soc. Geol. España 2007, 20, 173-185.

54. Groune, K.; Halim, M.; Lemée, L.; Benmakhlouf, M.; Amblés, A. Chromatographic study of the organic matter from Moroccan Rif bituminous rocks. Arab. J. Chem. 2019, 12, 1552-1562. [CrossRef]

55. Berggren, W.A.; Kent, D.V.; Swisher, C.C.; Aubry, M.-P. A revised Cenozoic geochronology and chronostratigraphy. In Geochronology, Time-Scales, and Global Stratigraphic Correlation; Berggren, W.A., Ed.; SEPM (Society for Sedimentary Geology) Special Publication: Tulsa, OK, USA, 1995; Volume 54, pp. 129-212.

56. Olsson, R.K.; Hemleben, C.; Berggren, W.A. (Eds.) Atlas of Paleocene Planktonic Foraminifera: Smithsonian Contributions to Paleobiology; Smithsonian Institution Press: Washington, DC, USA, 1999; Volume 85, p. 252.

57. Berggren, W.A.; Pearson, P.P. A revised tropical to subtropical planktonic foraminiferal zonation of the Eocene and Oligocene. J. Foraminifer. Res. 2005, 35, 279-298. [CrossRef]

58. Berggren, W.A.; Pearson, P.N. Tropical and subtropical planktonic foraminiferal zonation of the Eocene and Oligocene. In Cushman Foundation Special Publication; Pearson, P.N., Olsson, R.K., Huber, B.T., Hemleben, C., Berggren, W.A., Eds.; Cushman Foundation: Fredericksburg, VA, USA, 2006; Volume 41, pp. $29-40$.

59. Wade, B.S.; Pearson, P.N.; Berggren, W.A.; Pälike, H. Review and revision of Cenozoic tropical planktonic foraminiferal biostratigraphy and calibration to the geomagnetic polarity and astronomical time scale. Earth Sci. Rev. 2011, 104, 11-142. [CrossRef]

60. Blow, W.H. Late middle Eocene to Recent planktonic foraminiferal biostratigraphy. In Proceedings of the 1st International Conference on Planktonic Microfossils; Bronniman, P., Renz, H., Eds.; EJ Brill Leiden: Geneva, Switzerland, 1969; Volume 1, pp. 199-422.

61. Iaccarino, S. Mediterranean Miocene and Pliocene planktic foraminifera. In Plankton Stratigraphy; Bolli, H.M., Saunders, J.B., Perch-Nielsen, K., Eds.; Cambridge University Press: Cambridge, UK, 1985; pp. 283-314.

62. Serrano, F. Biostratigraphic control of Neogene volcanism in Sierra de Gata (south-east Spain). Geol. Mijnb. 1992, 71, 3-14.

63. Di Stefano, A.; Foresi, L.M.; Lirer, F.; Iaccarino, S.M.; Turco, E.; Amore, F.O.; Morabito, S.; Salvatorini, G.; Mazzei, R.; Abdul Aziz, H. Calcareous plankton high resolution bio-magnetostratigraphy for the Langhian of the Mediterranean area. Riv. Ital. Paleontol. Stratigr. 2008, 114, 51-76.

64. Lourens, L.J.; Hilgen, F.J.; Laskar, J.; Shackleton, N.J.; Wilson, D. The Neogene Period. In A Geologic Time Scale; Gradstein, F.M., Ogg, J.G., Smith, A.G., Eds.; Cambridge University Press: Cambridge, UK, 2004; pp. 409-440.

65. Gazzi, P. Le arenarie del flysch supracretaceodell'Appennino modenese; correlazioni con il flysch di Monghidoro. Mineral. Petrogr. Acta 1966, 12, 69-97.

66. Dickinson, W.R. Interpreting detrital modes of greywacke and arkose. J. Sediment. Petrol. 1970, 40, 695-707.

67. Ingersoll, R.V.; Bullard, T.F.; Ford, R.L.; Grimm, J.P.; Pickle, J.D.; Sares, S.W. The effect of grain size on detrital modes: A test of the Gazzi-Dickinson point-counting method. J. Sediment. Petrol. 1984, 54, 103-116.

68. Zuffa, G.G. Hybrid arenites: Their composition and classification. J. Sediment. Petrol. 1980, 50, $21-29$.

69. Zuffa, G.G. Optical analyses of arenites: Influence of methodology on compositional results. In Marine Clastic Sedimentology; Zuffa, G.G., Ed.; Springer Science and Business Media LLC: Berlin/Heidelberg, Germany, 1985; Volume 148, pp. 165-189. 
70. Zuffa, G.G. Unravelling hinterland and offshore palaeogeography from deep-water arenites. In Marine Clastic Sedimentology, Models and Case Studies (a Volume in Memory of C. Tarquin Teatle); Leggett, J.K., Zuffa, G.G., Eds.; Graham and Trotman: London, UK; Haughton, LA, USA, 1987; pp. 39-61.

71. Fontana, D.; Zuffa, G.G.; Garzanti, E. The interaction of eustasy and tectonism from provenance studies of the Eocene Hecho Group turbidite complex (South-Central Pyreneees, Spain). Basin Res. 1989, 2, 223-237. [CrossRef]

72. Martín-Ramos, J.D.; Díaz-Hernández, J.L.; Cambeses, A.; Scarrow, J.H.; López-Galindo, A. Pathways for quantitative analysis by X-ray diffraction. In An Introduction to the Study of Mineralogy; Aydinalp, C., Ed.; IntechOpen: Rijeka, Croatia, 2012; pp. 73-92.

73. Holtzapffel, T. Les minéraux argileux: Préparation, analyse diffractométrique et détermination. Soc. Géol. Nord Publ. 1985, 12, 136.

74. Moore, D.M.; Reynolds, R.C. X-ray Diffraction and the Identification and Analysis of Clay Minerals, 2nd ed.; Oxford University Press: Oxford, UK, 1997; p. 378.

75. Biscaye, P.E. Mineralogy and sedimentation of recent deep sea clay in the Atlantic Ocean and adjacent seas and oceans. Geol. Soc. Am. Bull. 1965, 76, 803-832. [CrossRef]

76. Esquevin, J. Influence de la composition chimique des illites sur la cristallinité. Bull. Centre Rech. 1969, 3, 147-154.

77. Eslinger, E.; Mayer, L.; Durst, T.; Hower, J.; Savin, S. A X-ray technique for distinguishing between detrital and secondary quartz in the fine grained fraction of sedimentary rocks. J. Sediment. Petrol. 1973, 43, 540-543.

78. Hunziker, J.C. The evolution of illite to muscovite: An example of the behavior of isotopes in low grade metamorphic terrains. Chem. Geol. 1986, 57, 31-40. [CrossRef]

79. Drits, V.A.; Sakharov, B.A.; Lindgreen, H.; Salyn, A. Sequential structure transformation of illite-smectite-vermiculite during diagenesis of Upper Jurassic shales from the North Sea and Denmark. Clay Miner. 1997, 32, 351-371. [CrossRef]

80. Guerrera, F.; Manuel Martín-Martín, M.; Tramontana, M. Evolutionary Models of the Cenozoic Basins of Central-Western Mediterranean Area: A Review of Methodological Approaches. Geosciences 2020, 10, 366. [CrossRef]

81. Martín-Martín, M.; Rey, J.; Alcalá-García, F.J.; Tosquella, J.; Deramond, J.; Lara-Corona, E.; Duranthon, F.; Antoine, P.O. Tectonic controls of the deposits of a foreland basin: An example from the Eocene Corbières-Minervois basin, France. Basin Res. 2001, 13, 419-433. [CrossRef]

82. Frizon de Lamotte, D.; Michard, A.; Saddiqi, O. Quelques développements recent sur la géodynamique du Maghreb. Comptes rendus Geosci. 2006, 338, 1-10. [CrossRef]

83. Guerrera, F.; Estévez, A.; López-Arcos, M.; Martín-Martín, M.; Martín-Pérez, J.A.; Serrano, F. Paleogene tectono-sedimentary evolution of the Alicante trough (external Betic zone, SE Spain) and its bearing in the timing of deformation of the sud-Iberian Margin. Geodin. Acta 2006, 19, 87-101. [CrossRef]

84. Guerrera, F.; Mancheño, M.A.; Martín-Martín, M.; Raffaelli, G.; Rodríguez-Estrella, T.; Serrano, F. Paleogene evolution of the Externl Betic Zone and geodynamic implications. Geol. Acta 2014, 12, 171-192.

85. Dickinson, W.R.; Beard, L.R.; Brakenridge, G.R.; Erjavec, J.L.; Ferguson, R.C.; Inman, K.F.; Knepp, R.A.; Lindberg, F.A.; Ryberg, P.T. Provenance of North American Phanerozoic sandstones in relation to tectonic setting. Geol. Soc. Am. Bull. 1983, 94, 222-235. [CrossRef]

86. Azdimousa, A.; Bourgois, J.; Asebriy, L.; Poupeau, G.; Montigny, R. Histoire thermique et surrection du Rif externe et des nappes de flyschs associées (Nord Maroc). Trav. Inst. Sci. Rabat 2003, 21, 15-26.

87. El Ouahabi, M.; Daoudi, L.; Fagel, N. Mineralogical and geotechnical characterization of clays from northern Morocco for their potential use in the ceramic industry. Clay Miner. 2014, 49, 35-51. [CrossRef]

88. Faleh, A.; Sadiki, A. Glissement rotationnel de Dhar El Harrag: Exemple d'instabilité de terrain dans le Prérif central (Maroc). Bull. Inst. Sci. Rabat 2002, 24, 41-48.

89. Khomsi, S.; Bédir, M.; Soussi, M.; Ben Jemia, M.G.; Ben Ismail-Lattrache, K. Highlight of middle-late Eocene compressional events in the subsurface of eastern Tunisia (Sahel): Generality of the Atlasic phase in North Africa. Comptes rendus Geosci. 2006, 338, 41-49. [CrossRef]

90. Khomsi, S.; Ben Jemia, M.G.; Frizon de Lamotte, D.; Maherssi, C.; Echihi, O.; Mezni, R. An overview of the late cretaceous-Eocene positive inversions and oligo-Miocene subsidence events in the foreland of the Tunisian atlas: Structural style and implications for the tectonic agenda of the Maghrebian atlas system. Tectonophysics 2009, 475, 38-582. [CrossRef] 
91. Belayouni, H.; Guerrera, F.; Martín Martín, M.; Serrano, F. Stratigraphic update of the Cenozoic Sub-Numidian formations of the Tunisian Tell (North Africa): Tectonic/sedimentary evolution and correlations along the Maghrebian Chain. J. Afr. Earth Sci. 2012, 64, 48-64. [CrossRef]

92. Belayouni, H.; Guerrera, F.; Martín Martín, M.; Serrano, F. Paleogeographic and geodynamic Miocene evolution of the Tunisian Tell (Numidian and Post-Numidian Successions): Bearing with the Maghrebian Chain. Int. J. Earth Sci. 2013, 102, 831-855. [CrossRef]

93. Vitale, S.; Zaghloul, M.N.; Tramparulo, F.D.A.; El Ouaragli, B. Deformation char- acterization of a regional thrust zone in the northern Rif (Chefchaouen, Morocco). J. Geodyn. 2014, 77, 22-38. [CrossRef]

94. Vitale, S.; Zaghloul, M.N.; El Ouaragli, B.; Tramparulo, F.D.A.; Ciarcia, S. Polyphase deformation of the Dorsale Calcaire Complex and the Maghrebian Flysch Basin Units in the Jebha area (Central Rif, Morocco): New insights into the Miocene tectonic evo- lution of the Central Rif belt. J. Geodyn. 2015, 90, 14-31. [CrossRef]

95. Gouiza, M.; Gharton, R.; Bertotti, G.; Andriessen, P.; Storms, J.E.A. Post-Variscan evolution of the Anti-Atlas belt of Morocco constrained from low-temperature geochronology. Int. J. Earth Sci. 2017, 106, 593-616. [CrossRef]

Publisher's Note: MDPI stays neutral with regard to jurisdictional claims in published maps and institutional affiliations.

(C) 2020 by the authors. Licensee MDPI, Basel, Switzerland. This article is an open access article distributed under the terms and conditions of the Creative Commons Attribution (CC BY) license (http://creativecommons.org/licenses/by/4.0/). 